\title{
FRACTIONATION OF SERUM PROTEINS IN HYPERPROTEINEMIA, WITH SPECIAL REFERENCE TO MULTIPLE MYELOMA
}

\author{
By ALEXANDER B. GUTMAN, DAN H. MOORE, ETHEL BENEDICT GUTMAN, \\ VIRGINIA MCCLELLAN, AND ELVIN A. KABAT \\ (From the Department of Medicine, and the Electrophoresis Laboratory, College of Physicians and \\ Surgeons, Columbia University; the Presbyterian Hospital and the \\ Neurological Institute, New York City)
}

(Received for publication July 30, 1941)

Investigation of the serum proteins in disease is handicapped by lack of clinically applicable methods for resolving the complex system of proteins present in blood serum into homogeneous components. The only fractionation now possible is into groups of proteins having like solubility characteristics or electrophoretic mobilities or sedimentation constants (depending upon the method employed) but varying in other properties and in composition (1). However, these methods, if rigidly standardized, give reproducible results and, in certain diseases, characteristic divergencies from normal patterns. The separations therefore, though arbitrary, have at least empirical value.

The present study deals with the empirical application of Howe's method (2) and the electrophoretic technique $(3,4)$ to fractionation of the serum proteins in various diseases presenting hyperproteinemia. Multiple myeloma is of special interest in this connection. Not only is the incidence and degree of hyperproteinemia unusually high $(5,6,7,8)$, but there is extraordinary variability in the composition of the protein increment $(7,9)$, as indicated by fractional precipitation with neutral salts $(5,10,11,12)$, by electrophoresis $(4,13)$, and by ultracentrifugation (13). The significance of these peculiarities has not been made clear.

To provide a common basis for consideration of our findings in hyperproteinemia, we have first cited results obtained in normal adult subjects. Serum protein partitions in a variety of chronic infections and in cirrhosis are then recorded to illustrate the uniform plan in distribution of globulin subfractions which characterizes hyperproteinemia of all such etiology. Some of our cases with elevated serum protein levels due to multiple myeloma likewise showed this conventional fractional distribution. Others, however, presented certain distinctive anomalies in both the Howe and electrophoretic patterns, which were found to be due in large part to BenceJones proteinemia and to be of value in diagnosis.

\section{METHODS}

Blood samples were withdrawn without prolonged tourniquet stasis.

Total nitrogen was determined in $0.5 \mathrm{ml}$. samples of serum, made up to $25 \mathrm{ml}$. with 0.9 per cent $\mathrm{NaCl}$ solution in a volumetric flask. Triplicate $4 \mathrm{ml}$. aliquots were digested in $100 \mathrm{ml}$. Pyrex Kjeldahl flasks, then steamdistilled in a modified Pregl micro-Kjeldahl apparatus into $5 \mathrm{ml}$. saturated boric acid (14) containing methyl red (recrystallized) indicator. Titration was carried out with $\mathrm{N} / 70 \mathrm{HCl}$, matching with a control containing $5 \mathrm{ml}$. boric acid-indicator mixture plus sufficient blank distillate to approximate the volume of the unknown. Non-protein nitrogen was determined by the Folin-Wu method.

The Howe technique has been carried out with precautions since November, 1937, to minimize the filtration error (15). The albumin fraction was determined in $\mathbf{1 . 0}$ ml. samples of serum. Thirty $\mathrm{ml}$. of a 22.2 per cent solution of sodium sulfate (Merck anhydrous nitrogenfree) were added in an incubator room maintained at $37^{\circ}$, where the mixture remained (with the usual precautions) for 3 hours to overnight. Nine $\mathrm{cm}$. Number $\mathbf{5 0}$ Whatman paper was used and the first filtrate, approximately 2/5 of the total volume, was discarded. Nitrogen was determined in triplicate $3 \mathrm{ml}$. aliquots of the last filtrate by the procedure indicated. The total serum globulin fraction was estimated by difference.

The "euglobulin" fraction was determined in $0.5 \mathrm{ml}$. samples of serum to which were added $15 \mathrm{ml}$. of 14 per cent sodium sulfate at $37^{\circ}$. Filtration was carried out with $7.0 \mathrm{~cm}$. Number 50 Whatman filter paper. The first portion of the filtrate, about $1 / 3$ of the total volume, was discarded. Nitrogen was determined in triplicate $3 \mathrm{ml}$. aliquots of the last portion of filtrate by the procedure indicated. The "pseudoglobulin I" fraction was estimated in 0.5 (or, if available, 1.0) ml. samples of serum in the same way, using 18 per cent sodium sulfate. The " pseudoglobulin II " fraction was estimated by difference. The conventional conversion factor 6.25 was applied to all fractions to calculate protein content from protein nitrogen values. 
The experiments in which urinary Bence-Jones proteins were added to normal serum (of the composition indicated in Table IV) were conducted as follows: Saturated ammonium sulfate solution was added to unacidified urine to 38 to $\mathbf{4 0}$ per cent saturation; such precipitate as formed was rejected. The saturation was then increased to 55 per cent, the Bence-Jones proteins centrifuged off, redissolved and reprecipitated once, dissolved in water and dialyzed in the cold until free of ammonium salts. To $3 \mathrm{ml}$. normal serum were added $15 \mathrm{ml}$. of the Bence-Jones protein solution; to $3 \mathrm{ml}$. samples of the mixture were then added $12.5 \mathrm{ml}$. sodium sulfate in $26.6,21.6$ and 16.8 per cent concentration to make the proper final strength for determination of " pseudoglobulin II," " pseudoglobulin I " and "euglobulin," respectively. After overnight precipitation, nitrogen was determined in the filtrates in the usual way.

The electrophoresis analyses were carried out by use of the Tiselius apparatus (3). This consists of a U-tube having a rectangular cross-section, the end walls of which have high optical quality so that light refraction caused by concentration gradients in the solution can be detected accurately. The colloidal solution is placed in the bottom half of the U-tube underneath a buffer against which it has been dialyzed until its conductivity and $\mathrm{pH}$ have assumed the same value as that of the buffer. To facilitate filling and recovery of material after separation, the electrophoresis cell (U-tube) is divided into sections with sliding flange plates, so that each section may be sealed off from the rest of the system. The tops of the U-tube connect to large buffer vessels containing electrodes. The whole is placed in a water bath thermostatically maintained at a low temperature $\left(1.5^{\circ} \mathrm{C}\right.$. in our work). A boundary is formed by aligning the section containing the colloidal solution with the rest of the cell. A constant voltage is applied to the electrodes causing a current to flow (since the solutions are conducting). Convectional disturbances due to heat are minimized by maintaining the mean temperature (temperature is highest at center and lowest at walls of cells) of the solution at the point where the change of density with temperature is least (temperature of maximum density). Convection limits the wattage which may be dissipated in the cell.

The current produces an electrical field throughout the cell. If the cell has uniform cross-sectional area, $A \mathrm{~cm}^{2}$, the field $E$ equals $I / K A$ where $I$ is the current in amperes and $K$ is the conductivity of the solution in reciprocal ohms. This electric field causes the different components of the colloidal mixture to migrate at a rate proportional to the statistical surface charge per unit area of the particles or molecules and in a direction determined by the sign of this charge. This rate of migration in $\mathrm{cm}$./ $\mathrm{sec}$. per unit field in volts per $\mathrm{cm}$. is designated as the mobility of the component.

Bending of light rays caused by concentration gradients at the boundaries of each component may be detected by various optical methods; in this work we have used the Toepler Schlieren method with the adaptations of Svensson (16) and of Longsworth (17). The area, $A$, under a peak caused by the boundary of a given component having an index gradient $d n / d x$ is, for the Longsworth scanning method,

$$
A=r a b m \int_{-\infty}^{+\infty} \frac{d n}{d x} d x \text {, }
$$

where $n$ is the index of refraction of a solution of known concentration, $x$ the distance measured along the cell, $r$ the ratio of the movement of the photographic plate to that of the Schlieren edge in front of the camera, $a$ the length of light path through the electrophoresis cell, $b$ the distance from the cell to the Schlieren edge and $m$ the magnification of the camera. For the Philpot or Svensson cylindrical lens method the pattern area is given by

$$
A=a b m_{1} m_{2} \cot \theta \int_{-\infty}^{+\infty} \frac{d n}{d x} d x,
$$

where $a$ is the length of light path through the cell, $b$ the distance from the cell to the diagonal slit, $m_{1}$ the magnification of the camera lens, $m_{2}$ the magnification of the cylindrical lens and $\theta$ the angle that the edge or slit makes with the horizontal. Comparative measurements may be made, however, by simply comparing the area for one component with another.

Our procedure was as follows: The samples of serum were diluted $1: 4$ or $1: 6$ with buffer, depending upon their protein concentration. The diluted samples were then dialyzed at constant volume in a bag made from viscose tubing, first against 1 liter of buffer for 1 day, then against 2 liters for a second day. In the experiments in which urine containing Bence-Jones protein was added to serum, $3.0 \mathrm{ml}$. of serum were diluted with $9.0 \mathrm{ml}$. of the urine. All analyses were made with either $0.05 \mathrm{M}$ barbiturate buffer (4) containing $0.025 \mathrm{M} \mathrm{LiCl}$ at $\mathrm{pH} 7.8$, or $0.02 M$ sodium phosphate buffer containing $0.15 \mathrm{M} \mathrm{NaCl}$ at $\mathrm{pH}$ 7.4, as indicated in Table IV. A potential gradient of 5.1 volts per $\mathrm{cm}$. was used with barbiturate buffer and 2.4 volts per $\mathrm{cm}$. with phosphate buffer. The mobilities are lower with the phosphate buffer than with the barbiturate due to lower $\mathrm{pH}$ and to the increased ionic concentration (which lowers the zeta potential) but the differences in the areas representing the various fractions are negligible. The electrophoretic $A / G$ ratios and percentage of various components were obtained by enlarging the photographic patterns six times, and measuring the areas by means of a planimeter.

\section{RESULTS AND DISCUSSION}

\section{Serum protein partitions in normal adults}

1. Total serum protein levels. Table I summarizes results by the Howe method in 46 healthy laboratory workers and students, in whom higher total protein and albumin values occur than in hospitalized control subjects. The spread of total protein values in this series is from 7.9 to 6.5 grams per cent, more than $4 / 5$ of the values lying within the relatively narrow limits of 7.6 to 6.9 grams per cent. These results correspond with the general experience. 
2. Serum albumins. Under subheading A of Table I are summarized 36 normal serum albumin values obtained by the Howe method with precautions to avoid loss of filtrate protein through adsorption on the filter paper (15). Comparative analyses in this laboratory confirm the observation (15) that serum albumin levels may be higher when such precautions are taken (as much as +0.3 gram per cent), though often the difference is insignificant ( $c f .18)$. The range of values under subheading $A-5.7$ to 4.7 grams per cent-as well as their distribution, is therefore at a somewhat higher level than the corresponding results under $\mathbf{B}$ and in some reports in the literature. Elimination of the filtration error

TABLE I

Partition of serum proteins by the Howe method: normal adults

(Results expressed in grams per $100 \mathrm{cc}$. serum)

\begin{tabular}{l|l|c|c|c|c|c|c|}
\hline \hline$\underset{\text { ber }}{\text { Num- }}$ & $\begin{array}{c}\text { Sex, } \\
\text { age }\end{array}$ & $\begin{array}{c}\text { Total } \\
\text { proteins }\end{array}$ & $\begin{array}{c}\text { Albu- } \\
\text { min }\end{array}$ & $\begin{array}{c}\text { Total } \\
\text { globulins }\end{array}$ & $\begin{array}{c}\text { Euglob- } \\
\text { ulin }\end{array}$ & Pseudoglobulins \\
\hline
\end{tabular}

A. RESULTS WITH MINIMAL ERROR OF FILTRATION

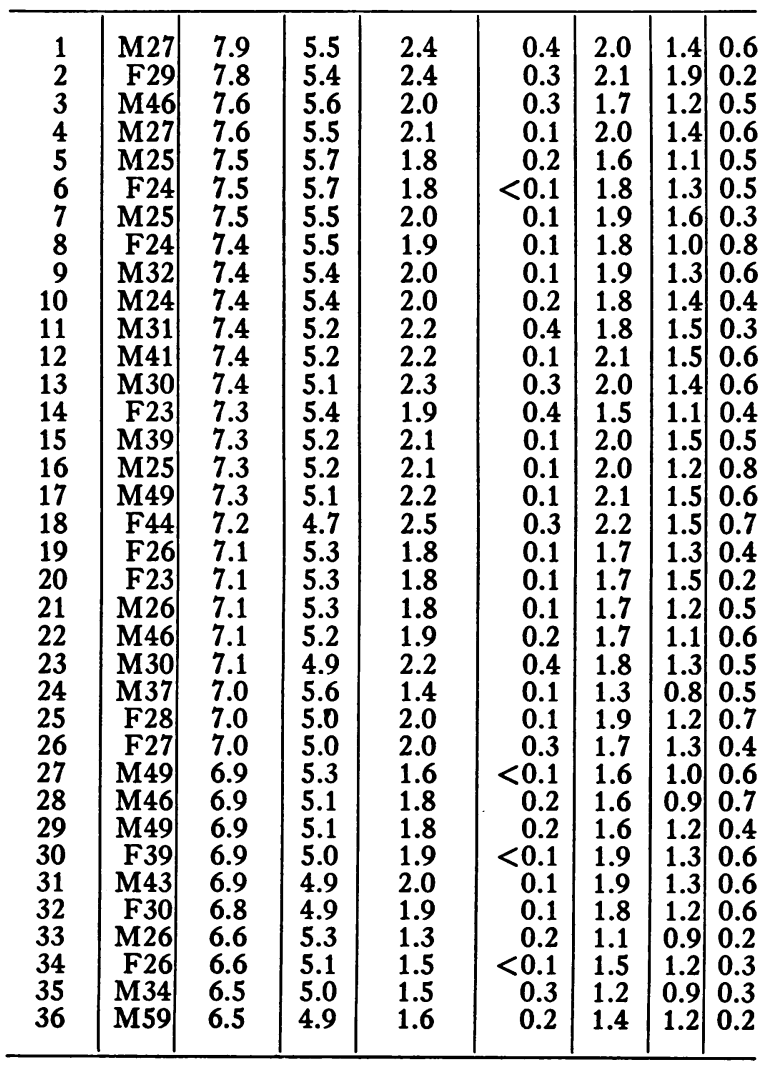

TABLE I-Continued

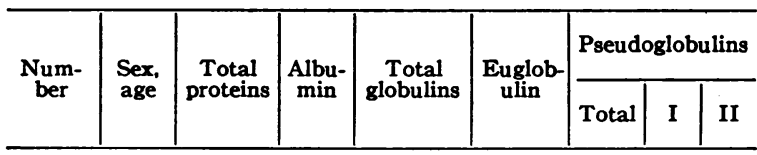

B. RESULTS WITH FORMER ERROR OF FILTRATION

\begin{tabular}{l|r|l|l|l|l|l|l|l}
37 & M30 & 7.6 & 4.9 & 2.7 & 0.5 & 1.8 & 1.3 & 0.9 \\
38 & M27 & 7.3 & 5.1 & 2.2 & 0.3 & 1.9 & 1.2 & 0.7 \\
39 & F25 & 7.3 & 4.8 & 2.5 & 0.4 & 2.1 & 1.3 & 0.8 \\
40 & F24 & 7.3 & 4.8 & 2.5 & 0.3 & 2.2 & 1.4 & 0.8 \\
41 & F24 & 7.2 & 5.0 & 2.2 & 0.4 & 1.8 & 1.1 & 0.7 \\
42 & M34 & 7.2 & 4.9 & 2.3 & 0.3 & 2.0 & 1.1 & 0.9 \\
43 & M41 & 7.2 & 4.8 & 2.4 & 0.6 & 1.8 & 1.2 & 0.6 \\
44 & F26 & 7.1 & 5.2 & 1.9 & 0.4 & 1.5 & 1.0 & 0.5 \\
45 & F25 & 6.9 & 4.6 & 2.3 & 0.4 & 1.9 & 1.1 & 0.8 \\
46 & M44 & 6.7 & 4.6 & 2.1 & 0.3 & 1.8 & 1.0 & 0.8
\end{tabular}

grams

Total proteins

Albumin

Total globulins

Euglobulin

Pseudoglobulin I (Group A):

Pseudoglobulin II (Group A):

\section{Mean $=7.2$}

Mean $=5.2$;

Mean $=2.0$

Mean $=0.2$

Mean $=1.3$;

Mean $=0.5$;

S.D. $=0.35$

S.D. $=0.25$

S.D. $=0.27$

S.D. $=0.11$

S.D. $=0.23$

S.D. $=0.16$

per cent

Total proteins

Albumin

Total globulins

Euglobulin

coefficient of variation $=5$

(Group A): coefficient of variation $=5$

(Group A): coefficient of variation $=14$

(Group A): coefficient of variation $=60$

Pseudoglobulin I (Group A): coefficient of variation $=17$ Pseudoglobulin II (Group A): coefficient of variation $=32$

in the Howe technique presumably leads to more accurate Howe values for the serum albumin fraction, which is not, however, thereby made less inhomogeneous.

3. Serum globulins. The spread of total serum globulin values under subheading A of Table I is from 2.5 to 1.3 grams per cent, with more than $3 / 4$ of the results falling between 2.2 and 1.6 grams per cent. For reasons indicated, the range and distribution of total globulin values under $\mathrm{A}$ are at slightly lower levels than the corresponding results under B. Only a small proportion of the total globulins in normal human serumfrom about 20 per cent to less than 5 per centis precipitable in $\mathbf{1 3 . 5}$ per cent sodium sulfate solution; in our series A the "euglobulin" fraction varied from 0.4 to less than 0.1 gram per cent. The major part of the globulins normally comes down in $\mathbf{1 7 . 4}$ per cent sodium sulfate, in series A this "pseudoglobulin I" fraction ranged from 1.9 to 0.8 gram per cent. The remaining globulins, precipitable in 21.5 per cent sodium sulfate ("pseudoglobulin II" fraction), made up 0.8 to 0.2 gram per cent. The globulin subfrac- 
TABLE II

Partition of serum proteins by the Howe method: hyperglobulinemia due to lymphogranuloma venereum, sarcoid, miscellaneous infections and cirrhosis

(Results expressed in grams per 100 cc. serum)

\begin{tabular}{|c|c|c|c|c|c|c|c|c|c|}
\hline \multirow{2}{*}{ Number } & \multirow{2}{*}{$\begin{array}{l}\text { Sex, } \\
\text { age }\end{array}$} & \multirow{2}{*}{ Diagnosis } & \multirow{2}{*}{\begin{tabular}{|c|} 
Total \\
proteins
\end{tabular}} & \multirow{2}{*}{ Albumin } & \multirow{2}{*}{$\begin{array}{c}\text { Total } \\
\text { globulins }\end{array}$} & \multirow{2}{*}{$\begin{array}{c}\text { Euglo- } \\
\text { bulin }\end{array}$} & \multicolumn{3}{|c|}{ Pseudoglobulins } \\
\hline & & & & & & & Total & I & II \\
\hline $\begin{array}{r}1 \\
2 \\
3 \\
4 \\
5 \\
6 \\
7 \\
8 \\
9 \\
10 \\
11 \\
12 \\
13 \\
14 \\
15 \\
16 \\
17 \\
18 \\
19 \\
20 \\
21 \\
22 \\
23 \\
24 \\
25 \\
26 \\
27 \\
28 \\
29 \\
30 \\
31 \\
32 \\
33 \\
34 \\
35 \\
36 \\
37 \\
38 \\
39 \\
40\end{array}$ & $\begin{array}{r}\text { F50 } \\
\text { F52 } \\
\text { F32 } \\
\text { M45 } \\
\text { F53 } \\
\text { M45 } \\
\text { M34 } \\
\text { M39 } \\
\text { F48 } \\
\text { M59 } \\
\text { M48 } \\
\text { F29 } \\
\text { F58 } \\
\text { F24 } \\
\text { F53 } \\
\text { M26 } \\
\text { F38 } \\
\text { F17 } \\
\text { M51 } \\
\text { F28 } \\
\text { F23 } \\
\text { F21 } \\
\text { F22 } \\
\text { F45 } \\
\text { M37 } \\
\text { M38 } \\
\text { F16 } \\
\text { M53 } \\
\text { M28 } \\
\text { F55 } \\
\text { F35 } \\
\text { F51 } \\
\text { M48 } \\
\text { M48 } \\
\text { M49 } \\
\text { F67 } \\
\text { M59 } \\
\text { M52 } \\
\text { M68 } \\
\text { M45 }\end{array}$ & $\begin{array}{l}\text { Lymphogranuloma venereum } \\
\text { Lymphogranuloma venereum } \\
\text { Lymphogranuloma venereum } \\
\text { Lymphogranuloma venereum } \\
\text { Lymphogranuloma venereum } \\
\text { Lymphogranuloma venereum } \\
\text { Lymphogranuloma venereum } \\
\text { Lymphogranuloma venereum } \\
\text { Lymphogranuloma venereum } \\
\text { Lymphogranuloma venereum } \\
\text { Sarcoid } \\
\text { Sarcoid } \\
\text { Sarcoid } \\
\text { Sarcoid } \\
\text { Sarcoid } \\
\text { Poikilodermatomyositis } \\
\text { Undiagnosed } \\
\text { Lupus erythematosus disseminatus } \\
\text { Hemolytic streptococcus bacteremia } \\
\text { Hemolytic streptococcus bacteremia } \\
\text { Lupus erythematosus disseminatus } \\
\text { Undiagnosed } \\
\text { Tuberculous lymphadenitis } \\
\text { Leprosy } \\
\text { Subacute bacterial endocarditis } \\
\text { Leukemia } \\
\text { Rheumatic fever, nephritis } \\
\text { Rheumatoid arthritis } \\
\text { Pylephlebitis } \\
\text { Undiagnosed } \\
\text { Cirrhosis } \\
\text { Cirrhosis } \\
\text { Cirrhosis } \\
\text { Cirrhosis } \\
\text { Cirrhosis } \\
\text { Cirrhosis } \\
\text { Cirrhosis } \\
\text { Cirrhosis } \\
\text { Cirrhosis } \\
\text { Cirrhosis }\end{array}$ & \begin{tabular}{r|}
11.2 \\
9.8 \\
9.2 \\
9.2 \\
9.1 \\
9.0 \\
8.1 \\
8.0 \\
7.9 \\
7.2 \\
9.7 \\
9.6 \\
8.3 \\
7.5 \\
7.0 \\
9.4 \\
8.9 \\
8.3 \\
8.3 \\
8.0 \\
7.9 \\
7.9 \\
7.9 \\
7.6 \\
7.3 \\
7.2 \\
7.2 \\
7.1 \\
7.0 \\
6.9 \\
7.7 \\
7.5 \\
7.3 \\
7.1 \\
6.9 \\
6.6 \\
6.5 \\
6.4 \\
5.7 \\
5.1
\end{tabular} & $\begin{array}{l}3.5 \\
3.7 \\
3.5 \\
3.3 \\
2.4 \\
2.7 \\
4.7 \\
3.2 \\
3.5 \\
3.7 \\
3.9 \\
4.2 \\
2.0 \\
3.8 \\
1.7 \\
4.4 \\
4.2 \\
3.0 \\
4.1 \\
4.3 \\
2.8 \\
3.8 \\
4.7 \\
3.4 \\
3.1 \\
3.4 \\
3.8 \\
3.5 \\
3.4 \\
2.7 \\
3.4 \\
2.4 \\
2.9 \\
2.9 \\
3.4 \\
2.1 \\
2.4 \\
1.6 \\
2.0 \\
2.1\end{array}$ & $\begin{array}{l}7.7 \\
6.1 \\
5.7 \\
5.9 \\
6.7 \\
6.3 \\
3.4 \\
4.8 \\
4.4 \\
3.5 \\
5.8 \\
5.4 \\
6.3 \\
3.7 \\
5.3 \\
5.0 \\
4.7 \\
5.3 \\
4.2 \\
3.7 \\
5.1 \\
4.1 \\
3.2 \\
4.2 \\
4.2 \\
3.8 \\
3.4 \\
3.6 \\
3.6 \\
4.2 \\
4.3 \\
5.1 \\
4.4 \\
4.2 \\
3.5 \\
4.5 \\
4.1 \\
4.8 \\
3.7 \\
3.0\end{array}$ & $\begin{array}{l}3.4 \\
2.2 \\
2.7 \\
1.8 \\
3.0 \\
2.0 \\
0.5 \\
1.0 \\
1.0 \\
1.1 \\
2.3 \\
2.1 \\
3.1 \\
0.9 \\
1.8 \\
1.9 \\
1.4 \\
1.9 \\
0.9 \\
0.9 \\
1.4 \\
0.8 \\
0.5 \\
0.9 \\
1.0 \\
0.7 \\
0.6 \\
0.9 \\
0.8 \\
0.8 \\
0.8 \\
1.1 \\
1.2 \\
1.1 \\
0.9 \\
1.1 \\
0.7 \\
1.6 \\
0.9 \\
0.5\end{array}$ & $\begin{array}{l}4.3 \\
3.9 \\
3.0 \\
4.1 \\
3.7 \\
4.3 \\
2.9 \\
3.8 \\
3.4 \\
2.4 \\
3.5 \\
3.3 \\
3.2 \\
2.8 \\
3.5 \\
3.1 \\
3.3 \\
3.4 \\
3.3 \\
2.8 \\
3.7 \\
3.3 \\
2.7 \\
3.3 \\
3.2 \\
3.1 \\
2.8 \\
2.7 \\
2.8 \\
3.4 \\
3.5 \\
4.0 \\
3.2 \\
3.1 \\
2.6 \\
3.4 \\
3.4 \\
3.2 \\
2.8 \\
2.5\end{array}$ & $\begin{array}{l}3.8 \\
3.3 \\
2.2 \\
3.4 \\
3.3 \\
3.7 \\
2.2 \\
3.2 \\
2.6 \\
2.1 \\
3.1 \\
2.8 \\
2.8 \\
2.3 \\
3.2 \\
2.5 \\
2.5 \\
2.4 \\
2.7 \\
2.2 \\
3.3 \\
2.7 \\
2.1 \\
2.7 \\
2.7 \\
2.5 \\
2.1 \\
2.0 \\
2.1 \\
2.8 \\
3.0 \\
3.7 \\
2.7 \\
2.7 \\
2.2 \\
2.9 \\
2.8 \\
3.0 \\
2.4 \\
2.2\end{array}$ & $\begin{array}{l}0.5 \\
0.6 \\
0.8 \\
0.7 \\
0.4 \\
0.6 \\
0.7 \\
0.6 \\
0.8 \\
0.3 \\
0.4 \\
0.5 \\
0.4 \\
0.5 \\
0.3 \\
0.6 \\
0.8 \\
1.0 \\
0.6 \\
0.6 \\
0.4 \\
0.6 \\
0.6 \\
0.6 \\
0.5 \\
0.6 \\
0.7 \\
0.7 \\
0.7 \\
0.6 \\
0.5 \\
0.3 \\
0.5 \\
0.4 \\
0.4 \\
0.5 \\
0.6 \\
0.2 \\
0.4 \\
0.3\end{array}$ \\
\hline
\end{tabular}

tions tend to be lower in the A than in the $B$ series but the difference is small in normal sera and becomes imperceptible in conditions causing hyperglobulinemia. ${ }^{1}$

Due to overlapping of precipitation limits, incomplete precipitation, adsorption, and other causes $(20,21)$, the separation ' of fractions by salting-out procedures such as Howe's method is

1 The terms "euglobulin," "pseudoglobulin I" and "pseudoglobulin II" will be used throughout in the sense employed by Howe, to designate arbitrarily defined serum protein mixtures precipitable, respectively, in 30 volumes of (approximately) 1.0, 1.25 and $1.5 M$ sodium sulfate solution. Each of these fractions contains both waterinsoluble and water-soluble serum globulins (19), the "euglobulins" and "pseudoglobulins" of classical usage. very imperfect, particularly with respect to the globulin subfractions. Moreover, the composition of fractions precipitable with the same concentration of salt may be quite different in different conditions. For example, the large "euglobulin" fraction in some cases of multiple myeloma doubtless contains proteins not present in the corresponding "euglobulin" fraction of normal serum and may be different in composition from the "euglobulin" fraction in infections.

\section{Serum protein partitions in chronic infections pre- senting hyperproteinemia, and in cirrhosis}

The diseases in which marked hyperglobulinemia commonly occurs, and which are there- 
fore suitable for study of the serum proteins in hyperproteinemia, fall into three main groups: certain chronic infections, cirrhosis and multiple myeloma. Data representative of results with the Howe method in chronic infections and in cirrhosis are summarized in Table II. Multiple myeloma, a special case, will be considered separately.

1. Total serum proteins. The disease most frequently represented in our series is lymphogranuloma venereum which, as indicated elsewhere $(22,23)$, is a common cause of marked hyperproteinemia in this area, as in many other localities (24, 25, 26, and others). Apart from multiple myeloma, all our total protein values of 10.0 grams per cent or over (as high as 11.7 grams per cent) occurred in lymphogranuloma venereum, with the exception of one case of kala-azar (11.4 grams per cent), one of sarcoid (10.0 grams per cent) and one of undetermined cause (10.0 grams per cent). Less marked and less consistent hyperproteinemia was observed in a variety of other conditions, as indicated in Table II.

2. Serum albumins. The significant features of the relation of serum albumin levels to total serum proteins, in diseases presenting hyperglobulinemia, are brought out in Figure 1. This figure includes 90 points representing results in 80 cases of lymphogranuloma venereum, 85 points in 70 patients with other infections, 70 points in 62 cases of cirrhosis and the 36 normal values of Table I A. There is clearly no correlation, positive or negative, between the albumin and the total protein content of the serum in these conditions. Serum albumin levels higher than those observed in normal subjects were not encountered (except in states of marked hemoconcentration); when the albumins are affected, as they are in a variety of debilitating conditions (27), the trend uniformly is downward irrespective of the total protein level. In cirrhosis the serum albumin content of ten is disproportionately low in relation to the total protein content. All these findings conform with the general experience.

3. Serum globulins. Data from the same cases presenting hyperglobulinemia are plotted in the lower part of Figure 1 to illustrate the wellrecognized relation of serum globulins to total

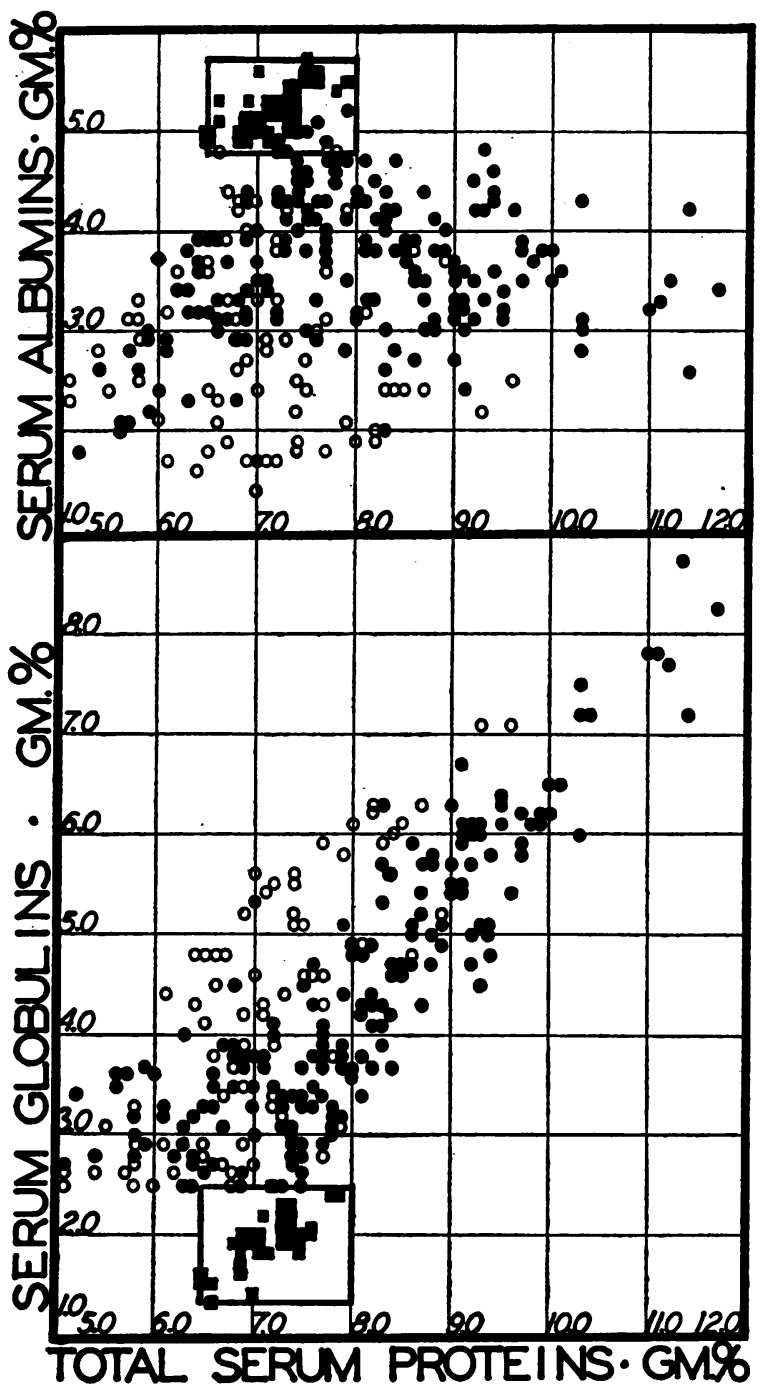

Fig. 1. Relation of Albumin Content (UPPER) and of Globulin Content (Lower) to Total Protein Content of Serum in Diseases Presenting HyperglobuLINEMIA

The solid dots represent cases of lymphogranuloma venereum and other infections; hollow dots represent cases of cirrhosis; squares are normal values, normal range enclosed by heavy lines.

protein levels. The points show a definite trend with a sharp, positive slope which reflects the direct proportionality between the total globulin and total protein content of the serum. The aberrant position of many points representing cases of cirrhosis is indicative of their disproportionately high globulin content. These points also show how frequently marked hyperglobulinemia, if accompanied by sufficiently de- 


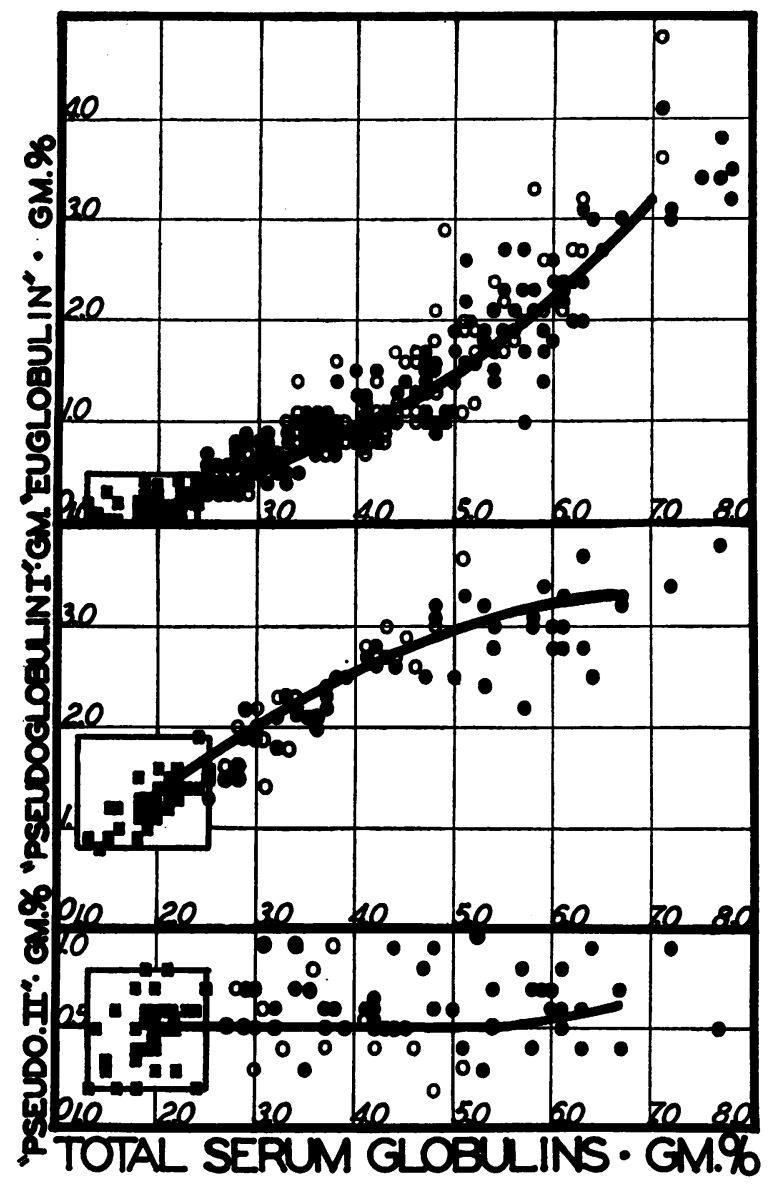

Fig. 2. Relation of "Euglobulin" Content (UPPER), "Pseudoglobulin I" CONTENT (Mid-Portion) AND "Pseudoglobulin II" Content (Lower) to Total Serum Globulins in Diseases Presenting HyperGLOBULINEMIA

Points differentiated as in Figure 1. Normal range enclosed by heavy lines.

creased serum albumin levels, may be associated with quite normal total protein values. Thus while hyperproteinemia implies hyperglobulinemia, normal total protein levels do not exclude the presence of significant hyperglobulinemia.

The interrelations of the several globulin subfractions in hyperglobulinemia are more obscure. Varied results with the Howe method have been recorded in the literature, but there are data relating to kala-azar $(28)$, cirrhosis $(10,29)$, lymphogranuloma venereum $(24,30)$, and other conditions, which indicate that increase in the globulin content of the serum is due to a rise in both "euglobulin" and "pseudoglobulin I" fractions, whereas the "pseudoglobulin II" fraction remains within essentially normal limits. This distribution of globulin subfractions has been found by some $(31,32$ and others) to apply very generally to chronic infectious diseases and cirrhosis presenting hyperglobulinemia; and this has been our experience (33), as indicated in Table II and Figure 2.

The upper part of Figure 2, showing the relation of the "euglobulin" fraction to the total serum globulin content, is made up of 90 points representing results in 80 cases of lymphogranuloma venereum, 50 points for 50 patients with other infections, 55 points for 50 cases of cirrhosis, and the 36 normal values of Table I A. The points show a definite trend with a positive slope which curves sharply upward in the higher globulin ranges. The figure clearly illustrates the fairly consistent increase in the Howe "euglobulin" fraction which accompanies any marked rise in total globulins. In Figure 3 we

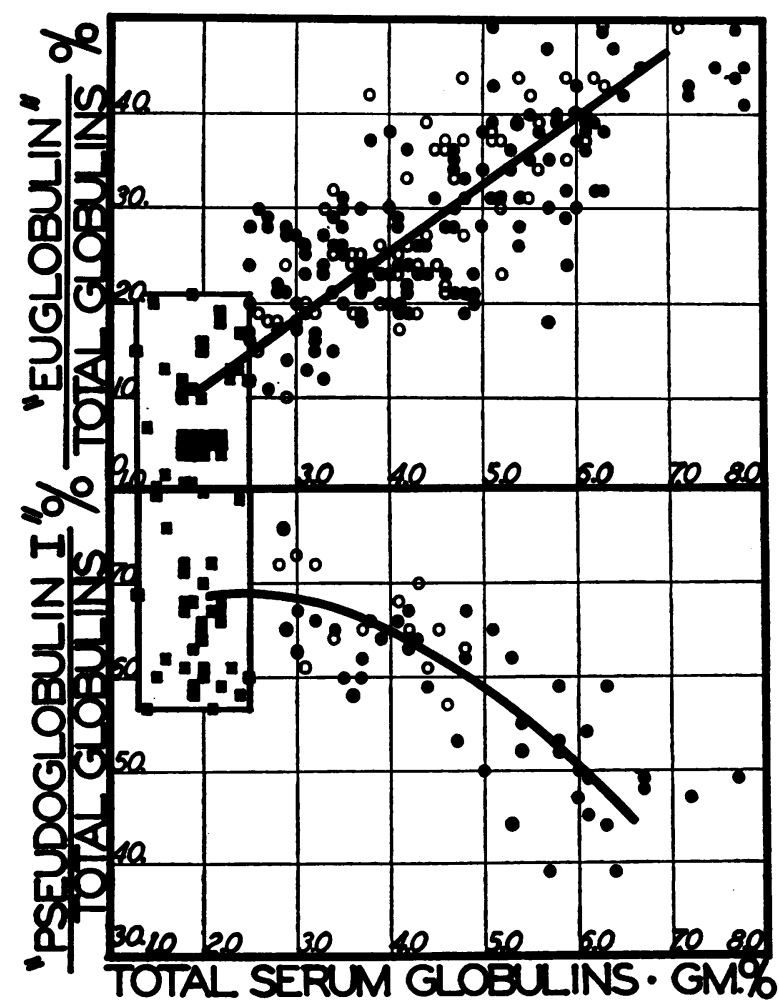

Fig. 3. Proportion of Total Serum Globulins Composed of "Euglobulin" (UPPer) and of "Pseudoglobulin I" (LOwer) at INCREASINg Serum Globulin LEVELS

Points differentiated as in Figure 1. Normal range enclosed by heavy lines. 
have plotted the same data to show the relation of the ratio "euglobulin"/total globulins, expressed in percentage, to the total serum globulin content. The dispersion here is large, but the generally upward trend is unmistakable, indicating that, as the total globulin content of the serum increases, a progressively larger proportion is composed of the Howe "euglobulin" fraction, i.e. the increase in "euglobulin" is relative as well as absolute. Thus in our normal sera, which contained a mean total globulin of 2.0 grams per $100 \mathrm{cc}$., the mean "euglobulin" content was $\mathbf{0 . 2}$ gram, or 10 per cent of the total globulins; the maximum normal percentage was about 20 . In abnormal sera containing 4.0 grams total globulins per $100 \mathrm{cc}$., the mean "euglobulin" content was 1.0 gram, or 25 per cent of the total globulins. In sera containing 6.0 grams total globulins per $100 \mathrm{cc}$., the mean "euglobulin" content was 2.3 grams, or almost 40 per cent of the total globulins. This represents a more than ten-fold increase in "euglobulin," as compared with the mean normal value.

That portion of Figure 2 dealing with the relation of the "pseudoglobulin I" fraction to the total serum globulin content is made up of 18 points representing results in 15 cases of lymphogranuloma venereum, 31 points for 30 patients with other infections, 18 points for 15 cases of cirrhosis, and the 36 normal values of Table I A. The points show a definite trend with a positive slope which flattens out in the higher globulin ranges: there is a distinct rise in "pseudoglobulin I" as the total globulin content increases, but beyond 5.0 grams per cent total globulins, there is no further consistent increase in "pseudoglobulin I." At such very high globulin levels, the globulin increment is composed largely of "euglobulin" and in extreme cases the latter (normally the smallest Howe fraction) may supersede "pseudoglobulin I" as the major globulin component. These relations are brought out more clearly in Figure 3, in which we have plotted the same data to show the ratio "pseudoglobulin I"/total globulins, expressed in percentage, at increasing levels of total globulins. The ratio remains within normal limits in moderate hyperglobulinemia but declines with further increase in total serum globulins, i.e. there is an absolute increase but, at least in the higher ranges, a relative decrease in the "pseudoglobulin I" fraction in hyperglobulinemia. To illustrate, the mean "pseudoglobulin I" content of our normal sera was 1.3 grams per $100 \mathrm{cc}$, constituting an average of roughly 65 per cent of the mean normal total globulins. In abnormal sera containing 4.0 grams total globulins per $100 \mathrm{cc}$., the mean "pseudoglobulin I" content was 2.5 grams, about 62 per cent of the total globulins. In sera containing 6.0 grams total globulins per $100 \mathrm{cc}$., the mean "pseudoglobulin I" content was 3.1 grams, or only 52 per cent of the total globulins. The highest "pseudoglobulin I" values encountered involved a three- to four-fold increase of the normal content.

The lower portion of Figure 2 shows the relation of the "pseudoglobulin II" fraction to the total serum globulin level in the cases considered in the preceding paragraph. There is no significant increase in the "pseudoglobulin II" fraction in hyperglobulinemia, the trend being parallel to the abscissa. The ratio "pseudoglobulin II"/ total globulins therefore decreases as the total globulin content increases. Thus our normal sera contained a mean of 0.5 gram "pseudoglobulin II" per 100 cc., or 25 per cent of the mean total globulin content. In marked hyperglobulinemia, this proportion often fell to less than 10 per cent (Table II).

It is evident that the Howe method, despite its deficiencies, gives reasonably uniform results when applied to fractionation of serum proteins in chronic infections and cirrhosis. Apart from the effects of hemoconcentration, hyperproteinemia in these conditions invariably is due to increase in globulins; and hyperglobulinemia in turn results from an orderly, progressive increase in globulins precipitable in 13.5 per cent sodium sulfate solution, together with a less sustained rise in globulins precipitable in 17.4 per cent sodium sulfate. Marked hyperglobulinemia due solely to one or the other of these two fractions, or to "pseudoglobulin II," was not observed in this group. ${ }^{2}$

The significance of these relations might be clarified by cross-comparisons with results ob-

2 An apparent exception, a case of cirrhosis reported by Wise and Gutman (34, Table I, Case 24) as 0.5 gram per cent euglobulin, 7.3 grams per cent total globulins, should read 3.5 grams per cent euglobulin. 
tained by other methods of fractionation; integrated studies like some which have been made with normal horse serum $(1,35)$. Such data relevant to hyperproteinemia are as yet very meager. The precipitin technique, applied to hyperglobulinemia due to lymphogranuloma venereum and cirrhosis by Kendall (19), indicates that the globulin increase is confined to the alpha fraction (analogous to the Tiselius $\gamma$ fraction); for example, Kendall found 4.9 grams per cent alpha globulin, as compared with the mean normal value of 1.4 grams per cent, in his Case M. J. (Table V; see Case 3, Table II of the present study for Howe fractions in this serum). Electrophoretic analyses in these diseases $((4,36)$, Figure 4 and Table IV) similarly suggest that most or all of the globulin increment moves with the mobility of $\gamma$ globulins. The large $\gamma$ component in these diseases may represent complexes dissociable, in strong salt solutions, into protein fractions (themselves inhomogeneous) which are precipitable in 13.5 or 17.4 per cent sodium sulfate solutions. If such complexes are formed, the relations between the Howe "euglobulin" and "pseudoglobulin I" fractions in hyperglobulinemia, indicated in Figures 2 and 3, perhaps reflect the proportions in which these components interact. ${ }^{3}$

Figure 4, illustrating the electrophoretic analysis of $13.5,17.4$ and 21.5 per cent sodium sulfate filtrates, is of interest in this connection. Serum L. V., from a case of lymphogranuloma venereum (Case 2, Table II), contained 6.1 grams per cent total globulins, of which 2.2 grams per cent were "euglobulin" and 3.3 grams per cent "pseudoglobulin I" by the Howe method. About onethird of the $\gamma$ but no significant proportion of

3 The presence of increased "euglobulin" and "pseudoglobulin I," or of complexes formed by them, is responsible for the various hyperglobulinemia reactions described in the literature (9). The accumulation of globulins binding little base results in apparent discrepancies in acid-base equivalence $(30,38)$. Discrepancies between observed serum calcium levels and those calculated by formulae relating serum calcium to total serum proteins similarly appear to be due to the accumulation of globulins binding little calcium (33). Drinker, Green and Hastings (39) have shown that very little calcium is bound by Green's euglobulin $_{\text {II }}$ fraction, which Svensson found to correspond electrophoretically with $\gamma$-euglobulin (37). As shown in Figure 4 , there is a marked increase in $\gamma$-euglobulins in hyperglobulinemia. the $\beta$ and $\alpha$ components was removed by precipitation in $\mathbf{1 3 . 5}$ per cent sodium sulfate. Following precipitation in $\mathbf{1 7 . 5}$ per cent sodium sulfate, the filtrate contained no $\gamma$ component, only the $\alpha$ component and a very small fraction of the $\beta$.

In normal human serum (Figure 4 ), the pattern is essentially unchanged after precipitation in 13.5 per cent sodium sulfate (this sample contained $<0.1$ gram per cent "euglobulin"). About one-half of the $\gamma$, one-fourth of the $\beta$ and none of the $\alpha$ components (all calculated in relation to the albumin content) were removed by precipitation in 17.4 per cent sodium sulfate.

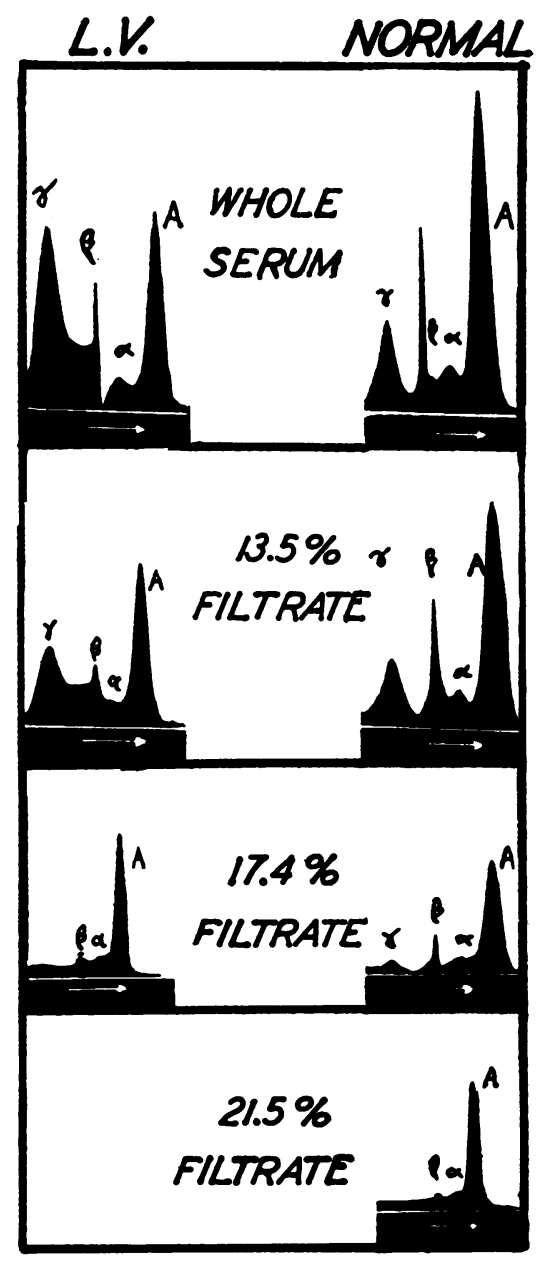

Fig. 4. Electrophoretic Patterns (Descending Limb) in Hyperglobulinemia DUe to Lymphogranuloma Venereum and in Normal Human Serum

The upper figures give results in whole serum; below these are patterns obtained in filtrates after fractional precipitation with sodium sulfate by Howe's method. 
TABLE III

Partition of serum proteins by the Howe method: multiple myeloma

(Results expressed in grams per 100 cc. serum)

\begin{tabular}{|c|c|c|c|c|c|c|c|c|c|c|c|}
\hline \multirow{2}{*}{$\underset{\text { ber }}{\text { Num- }}$} & \multirow{2}{*}{$\begin{array}{l}\text { Sex, } \\
\text { age }\end{array}$} & \multirow{2}{*}{ Date } & \multirow{2}{*}{$\begin{array}{l}\text { Total } \\
\text { pro- } \\
\text { teins }\end{array}$} & \multirow{2}{*}{$\underset{\text { min }}{\text { Albu- }}$} & \multirow{2}{*}{$\begin{array}{l}\text { Total } \\
\text { glob- } \\
\text { ulins }\end{array}$} & \multirow{2}{*}{$\begin{array}{l}\text { Eu- } \\
\text { glob- } \\
\text { ulin }\end{array}$} & \multicolumn{3}{|c|}{$\begin{array}{l}\text { Pseudo- } \\
\text { globulins }\end{array}$} & \multirow{2}{*}{$\begin{array}{l}\text { Bence- } \\
\text { Jones } \\
\text { protein } \\
\text { in urine }\end{array}$} & \multirow{2}{*}{ Basis for diagnosis } \\
\hline & & & & & & & Total & I & II & & \\
\hline
\end{tabular}

A. Cases with hyperproteinemia

1. HYPERGLOBULINEMTA WITH HYPEREUGLOBULINEMIA
\begin{tabular}{l|lrr|r|r}
$3 . \quad M 63$ & April & 18,1939 & 10.6 & 2.6 \\
April & 25,1939 & 12.0 & 2.6 \\
May & 4,1939 & 9.6 & 2.3
\end{tabular}
4. M39 February 1,1935 10.0 3.2
\begin{tabular}{ll|l|r|r} 
5. & F57 & August $\quad 25,1936$ & 9.2 & 2.6
\end{tabular} September 29, 1936

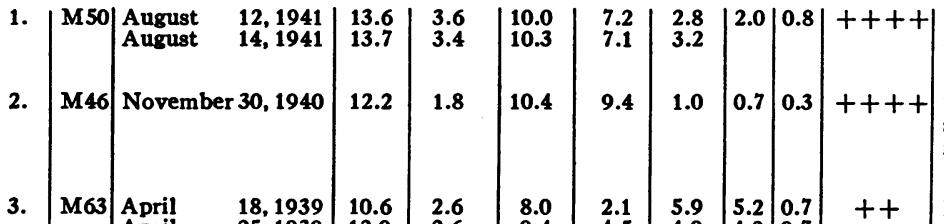

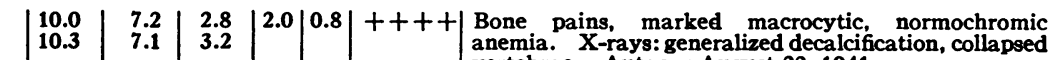 vertebrae. Autopsy August 22, 1941.
Tumor of skull, hemorrhages, marked hyperchromic anemia, bone pain. X-rays: osteolytic area calvarium generalized decalcification. Autopsy December 7. 1940. February 13, 1935 $11.0 \quad 3.5$ \begin{tabular}{ll|l|l} 
April & 23,1935 & 10.3 & 4.2
\end{tabular}
\begin{tabular}{llll|l|l} 
6. & M56 & October & 18,1940 & 9.5 & 3.2
\end{tabular}

9.4
7.3
\begin{tabular}{l|l|l|l}
4.5 & 4.9 & 4.2 & 0.7
\end{tabular}
\begin{tabular}{l|l|l|l|l}
3.9 & 3.4 & 2.7 & 0.7
\end{tabular}
\begin{tabular}{ll|l|l|l|l}
6.8 & 4.1 & 2.7 & 1.9 & 0.8 & 0
\end{tabular}
\begin{tabular}{l|l|l|l|l|}
7.5 & 4.6 & 2.9 & 1.9 & 0.8 \\
\hline 6.1 & 3.6 & 2.9 & 2.0 & 0.9
\end{tabular}

6.1
\begin{tabular}{l|l|l|l|c}
2.3 & 3.8 & & & ++++ \\
4.7 & 1.9 & 1.2 & 0.7 & 0
\end{tabular}
Pain in back, chest; dyspnea, uremia. X-rays: osteolytic areas ribs, skull, spine. Autopsy May 6 , 1939.
Chest pains, weakness, fever, marked hyperchromic topsy February 18, 1936 .
\begin{tabular}{ll|lrr|r|r} 
7. & M58 & & & & \\
June & 11,1940 & 8.1 & 3.6 \\
October & 3,1940 & 10.6 & 2.7 \\
October & 10,1940 & 11.1 & 2.5 \\
8. & F58 & Mctober & 21,1939 & 9.5 & 3.5 \\
November & 4,1939 & 9.0 & 4.3 \\
& M58 & May & 11,1936 & 8.6 & 3.8
\end{tabular}
\begin{tabular}{l|l|l|l|l|l}
4 & 1.9 & 1.2 & 0.7 & 0 & Weight loss, pain in chest, dyspnea, marked anemia.
\end{tabular}
1.7

\begin{tabular}{|l|} 
\\
4.5 \\
7.9 \\
8.6 \\
\\
6.0 \\
4.7 \\
4.8
\end{tabular}

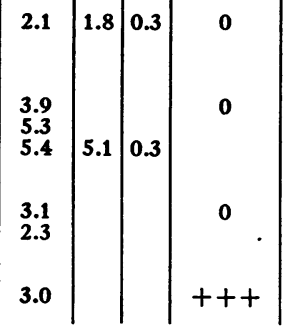 X-rays: skeleton negative. Autopsy October 19, 1936.
Bone pains, anemia. X-rays: generalized decalcifica- tion, collapsed vertebrae, punched-out areas femora. Autopsy October 25, 1940. Case of Dr. J.Tullis.
Pain in spine, ribs; weight loss, anemia. $\mathrm{X}$-rays: multiple osteolytic areas ribs, spine. Hypercalcemia. No primary visceral tumor found. Case of Dr. I. Woodruff.
Moderate weakness, bone pain. $\mathrm{X}$-rays: extensive punched-out areas in bones. No primary visceral tumor found. Case of Dr. L. Cotter.

2. HYPERGLOBULINEMIA WITHOUT HYPEREUGLOBULINEMIA

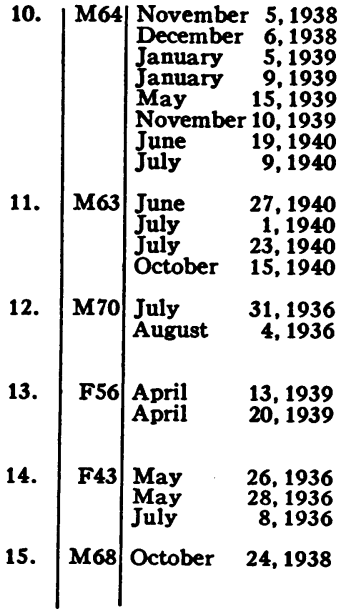

\begin{tabular}{r|r}
9.4 & 2.9 \\
9.4 & 2.7 \\
9.0 & 2.4 \\
8.9 & 2.4 \\
9.9 & 2.5 \\
9.8 & 2.5 \\
9.9 & 2.2 \\
10.2 & 2.7 \\
8.2 & $6.2 *$ \\
8.1 & 6.0 \\
8.4 & 6.7 \\
7.6 & 5.5 \\
10.9 & 2.5 \\
11.1 & 2.3 \\
& \\
9.1 & 4.0 \\
8.3 & 3.7 \\
& \\
8.0 & 3.5 \\
8.0 & 3.4 \\
6.4 & 3.2 \\
9.4 & 3.8 \\
&
\end{tabular}

\begin{tabular}{|r|r|r|r|r|r}
6.5 & $<0.1$ & 6.5 & & & 0 \\
6.7 & $<0.1$ & 6.7 & & & \\
6.6 & $<0.1$ & 6.6 & 4.3 & 2.3 & \\
6.5 & $<0.1$ & 6.5 & 3.8 & 2.7 & \\
7.4 & $<0.1$ & 7.4 & 6.3 & 1.1 & \\
7.3 & 0.3 & 7.0 & 5.9 & 1.1 & \\
7.7 & $<0.1$ & 7.7 & 6.8 & 0.9 & \\
7.5 & $<0.1$ & 7.5 & 6.8 & 0.7 & \\
$2.0 *$ & $<0.1$ & 2.0 & & & ++++ \\
2.1 & 0.1 & 2.0 & & & \\
1.7 & $<0.1$ & 1.7 & & & \\
2.1 & $<0.1$ & 2.1 & 1.2 & 0.9 & \\
8.4 & 0.3 & 8.1 & 7.5 & 0.6 & +++ \\
8.8 & 0.4 & 8.4 & & & \\
& & & & & \\
5.1 & 0.8 & 4.3 & 3.6 & 0.7 & 0 \\
4.6 & 0.4 & 4.2 & 3.6 & 0.6 & \\
& & & & & \\
4.5 & 0.5 & 4.0 & & & 0 \\
4.6 & 0.7 & 3.9 & & & \\
3.2 & 0.6 & 2.6 & & & \\
5.6 & $<0.1$ & 5.6 & & & \\
& & & & &
\end{tabular}

Weakness, gastro-intestinal bleeding, marked hyperchromic anemia. X-rays: slight generalized decalcification. Autopsy July 10, 1940.

3. HYPERPROTEINEMAA, GLOBULIN SUBFRACTIONS NOT DETERMINED

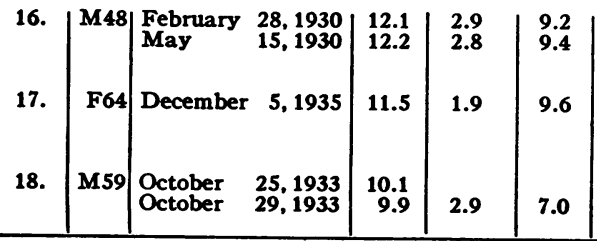
0 Weight loss, weakness, dyspnea, marked normochromic anemia. X-rays: skeleton negative. Autopsy April 8, 1931.†

Weakness, chest pain, dyspnea, tumor of chest wall uremia. X-rays: extensive osteolytic areas skeleton. Autopsy October 27, 1940.

Bone pains chest, back; weight loss; tumors of skull. $X$-rays: many punched-out areas ribs, spine, pelvis. Hypercalcemia. Plasma cells in blood smear.

Bone pains back, chest; weight loss, anemia. X-rays: osteolytic areas ribs with large soft tissue mass attached. Case of Dr. I. Woodruff.

Autopsy July 23, 1936. For details see Holman (40).

Bone pains. $\mathrm{X}$-rays: numerous punched-out areas in many skeletal parts; pathological fractures. Case of
Dr. J. Olpp. 
TABLE III-Continued

\begin{tabular}{|c|c|c|c|c|c|c|c|c|c|c|c|}
\hline \multirow{2}{*}{$\underset{\text { ber }}{\text { Num- }}$} & \multirow{2}{*}{$\begin{array}{l}\text { Sex, } \\
\text { age }\end{array}$} & \multirow{2}{*}{ Date } & \multirow{2}{*}{$\begin{array}{c}\text { Total } \\
\text { pro- } \\
\text { teins }\end{array}$} & \multirow{2}{*}{$\underset{\text { min }}{\text { Albu- }}$} & \multirow{2}{*}{$\begin{array}{l}\text { Total } \\
\text { glob- } \\
\text { ulins }\end{array}$} & \multirow{2}{*}{$\begin{array}{l}\text { Eu- } \\
\text { glob- } \\
\text { ulin }\end{array}$} & \multicolumn{3}{|c|}{$\begin{array}{l}\text { Pseudo- } \\
\text { globulins }\end{array}$} & \multirow{2}{*}{$\begin{array}{c}\text { Bence- } \\
\text { Jones } \\
\text { protein } \\
\text { in urine }\end{array}$} & \multirow{2}{*}{ Basis for diagnosis } \\
\hline & & & & & & & Total & I & II & & \\
\hline
\end{tabular}

3. HYPERPROTEINEMIA, GLOBULIN SUBFRACTIONS NOT DETERMINED-Continued

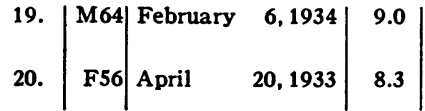
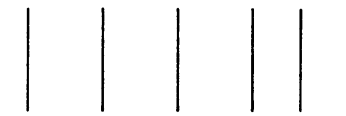
$+\quad \begin{aligned} & \text { Autopsy February 26, } 1934 \text {. For details see Gutman, } \\ & \text { Tyson, Gutman (41), Table III, Case 1. } \\ & \text { For clinical and x-ray evidence see Gutman, Tyson, }\end{aligned}$

B. Cases with total serum proteins $<8.0$ grams per cent

4. NORMAL TOTAL SERUM PROTEIN LEVELS WITH HYPERGLOBULINEMIA

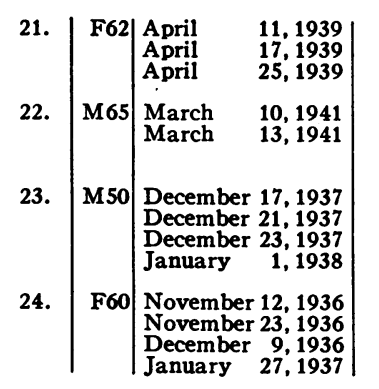

\begin{tabular}{|r|r|r|r|r|r|r|}
7.1 & 3.3 & 3.8 & 0.2 & 3.6 & & \\
7.4 & 3.6 & 3.8 & $<0.1$ & 3.8 & 3.1 & 0.7 \\
7.9 & 3.8 & 4.1 & 0.1 & 4.0 & 3.4 & 0.6 \\
7.8 & 2.6 & 5.2 & 0.2 & 5.0 & & \\
7.5 & 2.5 & 5.0 & 0.2 & 4.8 & 4.0 & 0.8 \\
& & & & & & \\
7.0 & 3.0 & 4.0 & 0.1 & 3.9 & & \\
7.1 & 2.8 & 4.3 & 0.2 & 4.1 & 3.2 & 0.9 \\
7.3 & 2.8 & 4.5 & 0.1 & 4.4 & & \\
6.9 & 2.5 & 4.4 & 0.2 & 4.2 & & \\
7.4 & 2.8 & 4.6 & 0.9 & 3.7 & & \\
7.4 & 2.9 & 4.5 & 1.2 & 3.3 & & \\
7.0 & 2.9 & 4.1 & 0.7 & 3.4 & &
\end{tabular}

0 Pain chest, weight loss, tumors of skull, hyperchromic anemia. X-rays: many punched-out areas in bones, fractures. Biopsy April 18, 1939.

0 Weight loss, weakness. X-rays: osteolytic areas femora, spine, ribs. Biopsy April 3,1941. Case of Dr. I. Woodruff.

$0 \quad$ Pain chest, back; paraplegia. X-rays: osteolytic areas spine, ribs; collapsed vertebra. Autopsy January 7, 1938.'

$0 \quad$ Bone pains, weight loss, weakness, fractures, tumors of scalp. X-rays: many punched-out areas in bones. Autopsy March 7, 1937 .

5. APPARENTLY NORMAL DISTRIBUTION OF SERUM PROTEIN FRACTIONS

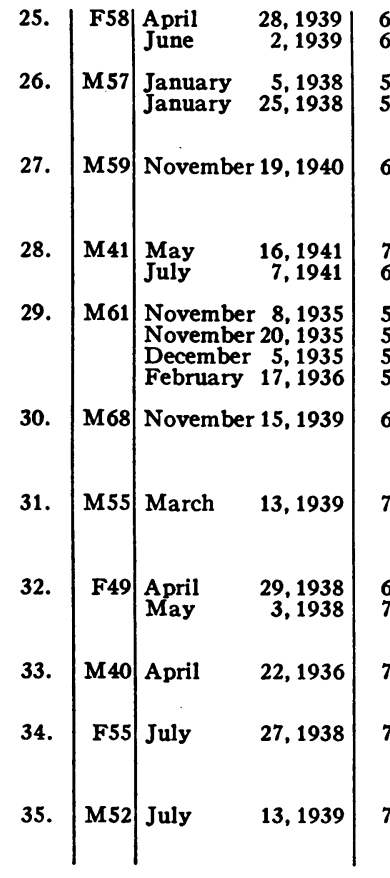

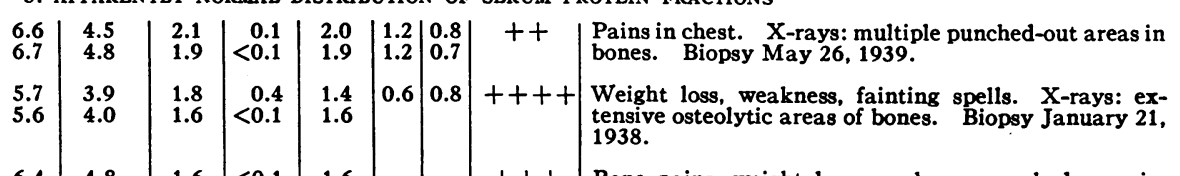

\begin{tabular}{ll|l|l|l|l|l|l}
6.4 & 4.8 & 1.6 & $<0.1$ & 1.6 & & &
\end{tabular}$\quad+++\quad$ Bone pains, weight loss, weakness, marked anemia. $X$-rays: many osteolytic areas in bones. Biopsy

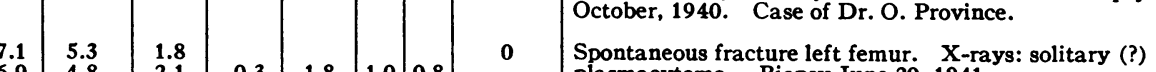

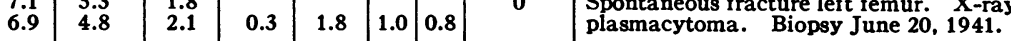

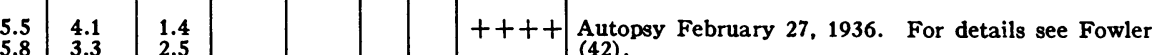

o Compression fracture vertebra with paraplegia. $\mathrm{X}$-rays: multiple punched-out areas in bones. Biopsy November 16, 1939.

Bone pains back, fracture. X-rays: osteolytic areas

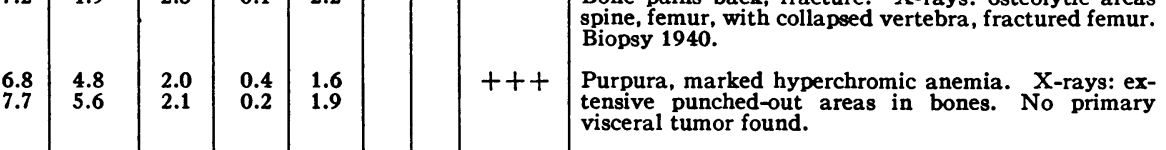

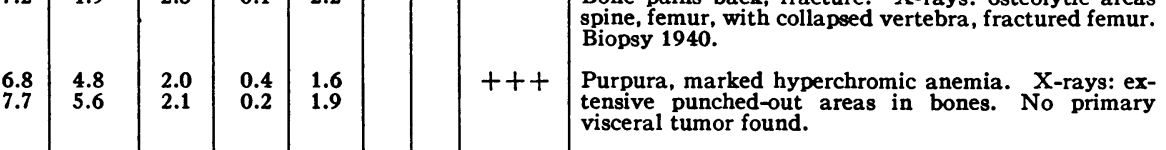

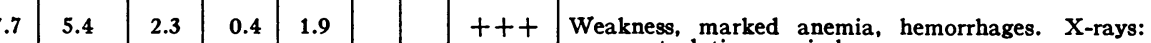
many osteolytic areas in bones.

$\pm \quad$ Large tumor skull, pain. X-rays: extensive osteolytic areas in bones with collapsed vertebra. No primary areas in bones with
visceral tumor found.

Bone pains back, chest; weight loss, dyspnea. X-rays: extensive punched-out areas bones. Autopsy July 17,
1939.

6. NORMAL TOTAL SERUM PROTEIN LEVELS, NOT FRACTIONATED

\begin{tabular}{l|l|lr|r} 
36. & M47 & February & 21,1934 & 6.3 \\
March & 1,1934 & 6.9 \\
37. & M60 & October & 24,1932 & 6.1
\end{tabular}

38. $\mid$ F58 $\mid$ May

For data see Gutman, Tyson, Gutman (41). Table III, Case 6.

For data see Gutman, Tyson, Gutman (41). Table III, Case 3.

7. MARKED HYPOPROTEINEMIA

* For reasons stated in the text, this case is included in the group with hyperglobulinemia.

† This case was presented elsewhere [(30); see Table IV, Case J. P.] as lymphosarcoma, a diagnosis made at autopsy performed at another hospital. The sections were reviewed by Dr. A. M. Pappenheimer and others who identified the tumor cells as myeloma (plasma) cells. 
All of the $\gamma$, about three-fourths of the $\beta$ and one-fourth of the $\alpha$ components were removed by precipitation in 21.5 per cent sodium sulfate. As indicated, the Howe albumin filtrate also contains appreciable amounts of $\alpha$ and $\beta$ components, presumably Hewitt's globoglycoid (37). The results in normal human serum correspond with those in normal horse serum fractionated with ammonium sulfate $(1,35,37)$.

\section{Serum protein partitions in multiple myeloma}

Table III summarizes our data with the Howe method in 38 cases of multiple myeloma. The diagnosis was established by autopsy or bone marrow biopsy in 26 patients; in 12 instances opportunity for histological examination was lacking and the diagnosis rests upon clinical, roentgenological and chemical evidence, as indicated in Table III. Except where specific acknowledgments are made, the cases are from the records of the Presbyterian Hospital for the years 1930 to 1941 .

It is obvious upon inspection of the data in Table III that multiple myeloma represents a special case in the distribution of serum protein fractions in hyperproteinemia, with anomalies that are without precedent in our experience with any other disease. In one instance (Case 11) hyperproteinemia appeared to be due to hyperalbuminemia; in another (Case 10) partly to a distinct increase in "pseudoglobulin II." In several instances, marked hyperglobulinemia appeared to result solely from increased "pseudoglobulin I" without any accompanying rise in "euglobulin." These peculiarities correspond with the experience of others who have found that hyperproteinemia in multiple myeloma may be due chiefly to increases in any of the following fractions: euglobulin $(5,6,43$, and others), pseudoglobulin I $(11,31,32$, and others), pseudoglobulin II $(10,32$, and others), albumin $(44,45$, and others), fibrinogen (43), Bence-Jones protein $(46$, and others), unclassified abnormal proteins $(47,48)$.

\section{A. Howe fractionation}

1. Total serum protein levels. Twenty patients presented protein levels of 8 grams per cent or more (Table III A), 18 did not have associated hyperproteinemia (Table III B). The values of 12.0 to 13.7 grams per cent encountered in Cases $1,2,3$ and 16 are the highest in our records. They are considerably lower, however, than have been reported in this disease (49, 50 , and others). The incidence of hyperproteinemia in our series, 53 per cent, is less than that of most estimates from published sources: 43 per cent (50); 57 per cent (33); 69 per cent (45); 175 of 282 cases or 62 per cent, according to our latest tally. But, owing to recent emphasis upon hyperproteinemia and related phenomena, the literature perhaps includes a disproportionate number of cases with elevated serum protein values.

Cases 26, 29 and 38 had total serum protein levels less than 6 grams per cent. The marked hypoproteinemia (3.5 grams per cent) observed in Case 38 corresponds with observations by Chester (51) and others.

2. Serum albumins. The serum albumin fraction in multiple myeloma, as in other wasting diseases, is usually decreased. The incidence of marked hypoalbuminemia seems to be unusually high: 12 of our cases presented levels less than 3.0 grams per cent, 9 of which on at least one occasion were 2.5 grams per cent or less. This proportion of marked hypoalbuminemia exceeds that in most infections or neoplasia and approaches the incidence in Laënnec's cirrhosis. No distinct correlation could be made out between the degree of proteinuria and the serum albumin content.

The apparent hyperalbuminemia of Patient 11, who was not dehydrated, was investigated further with the following results: $(a)$ High "albumin" values were not obtained if the serum-22.2 per cent sodium sulfate mixture remained 48 hours at $37^{\circ}$ before filtration. A sample repeatedly yielding 6.0 grams per cent filtrate protein after 3 hours' precipitation gave only 4.4 grams per cent filtrate protein if filtration was carried out after 48 hours' precipitation. A subsequent sample containing 6.7 grams per cent filtrate protein, if 3 or 24 hours were allowed for precipitation, gave only 4.5 grams per cent protein in filtrates obtained after 48 hours. (b) Precipitation in 21.5 per cent sodium sulfate buffered to $\mathrm{pH} 6.8$ yielded 3.7 grams per cent filtrate protein, as compared with 6.0 grams per cent obtained with unbuffered solutions. (c) A sample of 
serum yielding 5.5 grams per cent protein in 21.5 per cent sodium sulfate filtrates gave only 4.7 grams per cent filtrate protein after precipitation with 23.0 per cent sodium sulfate. (In our experience, these variations in the saltingout technique ordinarily cause only insignificant changes in the results of serum albumin determinations.) Electrophoretic fractionation showed 4.1 grams per cent albumin in the serum sample which by Howe's method contained 6.0 grams per cent filtrate protein after 3 hours' precipitation and 4.4 grams per cent after 48 hours. The precipitin technique, applied to a sample of this serum by Dr. F. E. Kendall, also indicated an albumin content of 4.1 grams per cent. Evidently, the serum in Case 11 contained about 2 grams per cent of a protein component which was not serum albumin but nevertheless remained in solution in 21.5 per cent sodium sulfate unless precipitation were allowed to continue much longer than prescribed by Howe. ${ }^{4}$

If such a protein component were present in lesser concentration, or superimposed upon a lower albumin content, the total "albumin" level might fall within normal limits and so escape attention. Several of the 11 cases in our series, with apparently normal distribution of Howe fractions (Table III B), presented "albumin" levels within normal limits but unexpectedly robust for patients who were distinctly wasted but not markedly dehydrated. Those with highest "albumin" levels (Case 32: 5.6 grams per cent; Case 33: 5.4 grams per cent; Case 35: 5.0 grams per cent) unfortunately were not studied further. But in Case 27, it could be shown electrophoretically that, of 4.8 grams per cent albumin indicated by Howe's method, only 3.2 grams per cent migrated with the mobility of serum albumin; and that an abnormal protein component was present, forming an extra boundary between the $\beta$ and $\gamma$ peaks. In Cases 25 and 28 similar, though less marked, differences were observed between salting-out and electrophoretic values for albumin. The conclusion seems warranted that, unless special precautions are taken, the Howe method (which gives high

\footnotetext{
${ }^{4}$ In Case 1, serum preserved with aseptic precautions in the refrigerator for about one week spontaneously changed to give lower albumin values by the usual Howe technique.
}

values for albumin in normal serum) occasionally gives much too high values for serum albumins in multiple myeloma; the error being due to an abnormal protein component, not albumin, in the 21.5 per cent sodium sulfate filtrate of some myelomatous sera. The error may be obvious because the "albumin" values become improbably high; more of ten perhaps the "albumin" levels do not exceed the normal maximum and escape correction.

3. Serum globulins. Total globulin levels over 3.0 grams per cent were found in 24 cases, inclusive of Cases 11,19 and 20 ; in the 2 latter instances, the proteins were not fractionated but the increased total content implies an increase in globulins. The levels of 9.0 to 10.4 grams per cent globulin in Cases 1, 2, 3, 16 and 17, though considerably lower than have been recorded in multiple myeloma, are the highest we have ever encountered in any disease. The incidence of hyperglobulinemia in our series (63 per cent) is greater than that of hyperproteinemia (53 per cent) because hyperglobulinemia in 4 cases was associated with lowering of the serum albumins sufficient to result in normal total protein levels.

In many cases of hyperglobulinemia due to multiple myeloma, the globulin increment was found to be composed of both "euglobulin" and "pseudoglobulin I," thus conforming with the characteristic pattern already described in chronic infections and in cirrhosis. This distribution of globulin subfractions was observed in our Cases 1 to 9 and 24. However, even in such apparently conventional myelomatous sera, the ratio "euglobulin"/total globulins is apt to be well outside the range of variation in this ratio observed in hyperglobulinemia due to other causes (Figure 3). The ratio may be excessively high because virtually all of the globulin increment is precipitable in 13.5 per cent sodium sulfate (Case 2); or unusually low (Cases 3 and 7). Similar sera containing increased "euglobulin" and "pseudoglobulin I," but in atypical proportions, have been reported by others.

A peculiarity of some sera in multiple myeloma is that definite hyperglobulinemia may be associated with no increase whatever in components precipitable in 13.5 per cent sodium sulfate ("euglobulin"), as first reported by Gros (10). His case showed marked elevation in both " pseu- 
doglobulin II" and "pseudoglobulin I" fractions (chiefly the former) without any rise in "euglobulin." This is a rare variant, even in multiple myeloma, and our series includes but one such case of hyperglobulinemia due chiefly to increase in "pseudoglobulin II" (Case 10, observations in early 1939). It is more common to find that the globulin increment (in hyperglobulinemia without hypereuglobulinemia) is composed almost in its entirety of components precipitable in 17.4 per cent sodium sulfate; an increased "pseudoglobulin I" fraction being the sole cause of hyperglobulinemia. Case 12 appears to have been the first recorded example of this anomaly (11), of which a number of instances have been described (31, 32, and others). In fact, this type of fractional distribution is of such high incidence (9 times in our present series, Cases 10 to 15,21 to 23 ) and is so characteristic of multiple myeloma that it has definite diagnostic value. ${ }^{5}$

4. Plasma fibrinogen. Determinations were made only in Cases 4 (0.4 gram per cent), 10 (0.2 gram per cent), 12 (0.4 gram per cent), $23(0.5$, later increased to 1.0 gram per cent) and 24 ( 0.3 gram per cent). So far as can be judged from these values and from the clotting of the blood in the remaining cases, hyperproteinemia due principally to hyperinosis did not occur in our series.

\section{B. Electrophoretic fractionation}

Longsworth, Shedlovsky and MacInnes (4) made the first electrophoretic studies in multiple myeloma (Cases 27, 28, 29 of their Table I; Cases 3, 21, 25, respectively, of this series, Tables III and IV). A marked increase in the $\beta$ globulin peak was observed in 2 cases, due to the presence of components migrating with the mobility of $\beta$ globulins; in one of these, the peak for fibrinogen also exceeded the limits for normal plasma. The third case yielded a normal pattern. Kekwick (13) reported results of electro-

\footnotetext{
5 In spite of the extraordinary variation in serum protein patterns in multiple myeloma, it should be noted that the fractional distribution in any one patient did not change in type while under observation. In 10 of our cases, protein studies were made over periods from one month to more than $1 \frac{1}{2}$ years. In no instance was there any striking change in pattern; minor changes accompanied further progression of the disease in 3 cases.
}

phoretic and ultracentrifugal analyses of sera in 5 cases of multiple myeloma. Four of these showed a great increase in the $\gamma$ globulin peak, associated with reduced percentage of albumin and essentially normal percentages of $\alpha$ and $\beta$ globulins. In the fifth case, $\gamma$ globulin was present in less than normal amount but there was a marked increase in a component migrating with a mobility corresponding with that of $\beta_{2}$ globulin.

Figure 5 and Table IV present electrophoretic data in sera of 7 additional cases of multiple myeloma. In Cases 1, 2 (Figure 5A) and 22 (Figure 5B) there was a very large increase in the $\gamma$ peaks. The two latter sera also contained an extra component (designated $M$ ), with a mobility between that of the $\beta$ and $\gamma$ components, corresponding with what in plasma would be the mobility of fibrinogen; the significance of this extra boundary will be considered later. The concentrations of albumin, $\alpha, \beta$, and $M$ were very low in the serum of Case 2 .

In Cases 10 and 11 (Figures 5C and D), there was a marked increase in components moving with the mobility of $\beta$ globulins. In Case 11, the mobility corresponded with that of the $\beta_{2}$ fraction; the faster $\beta_{1}$ component being indicated by a slight thickening on the forward side of the $\beta$ peak. Neither of these sera showed any increase in $\gamma$ globulins, nor was there any indication of an $M$ boundary.

The serum of Case 27 (Figure 5E) gave an electrophoretic pattern simulating that of normal plasma: an extra component, $M$, was present. The serum of Case 28 (Figure $5 \mathrm{~F}$ ) yielded a normal pattern.

When the results of electrophoretic and Howe fractionations are compared (Table IV), the correspondence between the distribution of protein fractions by these two methods is found to be imperfect. In Cases 1 and 2 (Figure 5A), the extremely high "euglobulin" content is reflected in very large $\gamma$ components; in Cases 10 (Figure 5C), 11 (Figure 5D), 21, 25, 27 (Figure $5 \mathrm{E}$ ), 28 (Figure $5 \mathrm{~F}$ ), normal or low normal "euglobulin" contents corresponded with normal or low normal $\gamma$ peaks. ${ }^{6}$ However, an

${ }^{6}$ Dr. F. E. Kendall examined the sera in Cases 10 and 11 by the precipitin method and found correspondingly low "globulin I" figures: 0.3 and 0.5 gram per cent, respectively, the mean normal value being 0.8 gram per cent. 

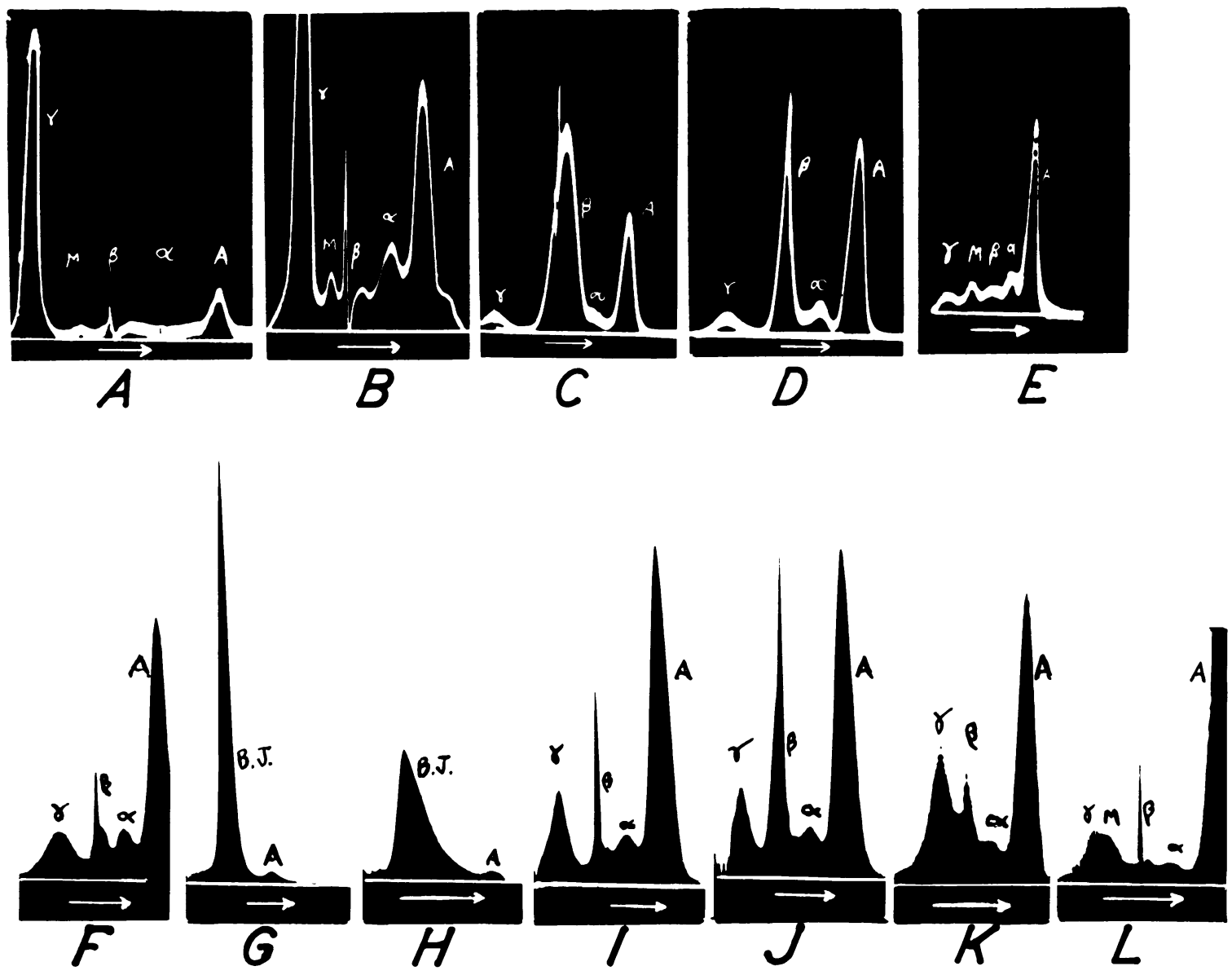

Fig. 5. Electrophoretic Patterns (Descendixg Limb) in Mlltiple Mreloma

A through $\mathrm{F}$ represents results in serum of Cases 2 (A), 22 (B), 10 (C), 11 (D), 27 (E), 28 (F). Patterns in urine of Cases $11(\mathrm{G})$ and $12(\mathrm{H})$ show peaks for Bence-Jones protein and albumin. I is normal serum to samples of which were added Bence-Jones proteins from the urine of Cases $11(\mathrm{~J}), 12(\mathrm{~K})$ and $3(\mathrm{~L})$. The patterns in the upper row were made with the Svensson cylindrical lens method.

extremely large $\gamma$ component in Case 22 (Figure 5B) was associated with normal "euglobulin" values by Howe's method, in which the globulin increment appeared solely in the "pseudoglobulin I" fraction. In Case 3 (Figure 5b of reference 4), an increase in both "euglobulin" and "pseudoglobulin I" appeared as very large increases in the $\beta$ and fibrinogen peaks.

In Cases 3, 10 and 21, large increases in "pseudoglobulin I" were reflected in large increases in components moving with the mobility of $\beta$ globulins; in Cases 1, 2, 25, 27 and 28, normal or low normal "pseudoglobulin I" values were associated with normal or low normal $\beta$ peaks. The discrepancy in this relation in Case 22 has been pointed out. In Case 11, a large $\beta$ peak was present, although no increase in the " pseudoglobulin I" fraction was apparent.

Large discrepancies in the albumin content of Cases 11 and 27, as determined by these two methods, have already been discussed. The presence of an extra component, $M$, in the electrophoretic analyses was in no instance revealed by the Howe method (for example, in the serum of Case 27, which appeared to be quite normal when examined by Howe's method). The plasma of Case 25 and the serum of Case 28 gave normal results by both methods.

\section{Bence-Jones proteinemia}

Significant Bence-Jones proteinemia presumably occurs in some cases of multiple myeloma 
SERUM PROTEIN FRACTIONS

TABLE IV

Comparison of results of fractionation of proteins by electrophoresis and Howe methods

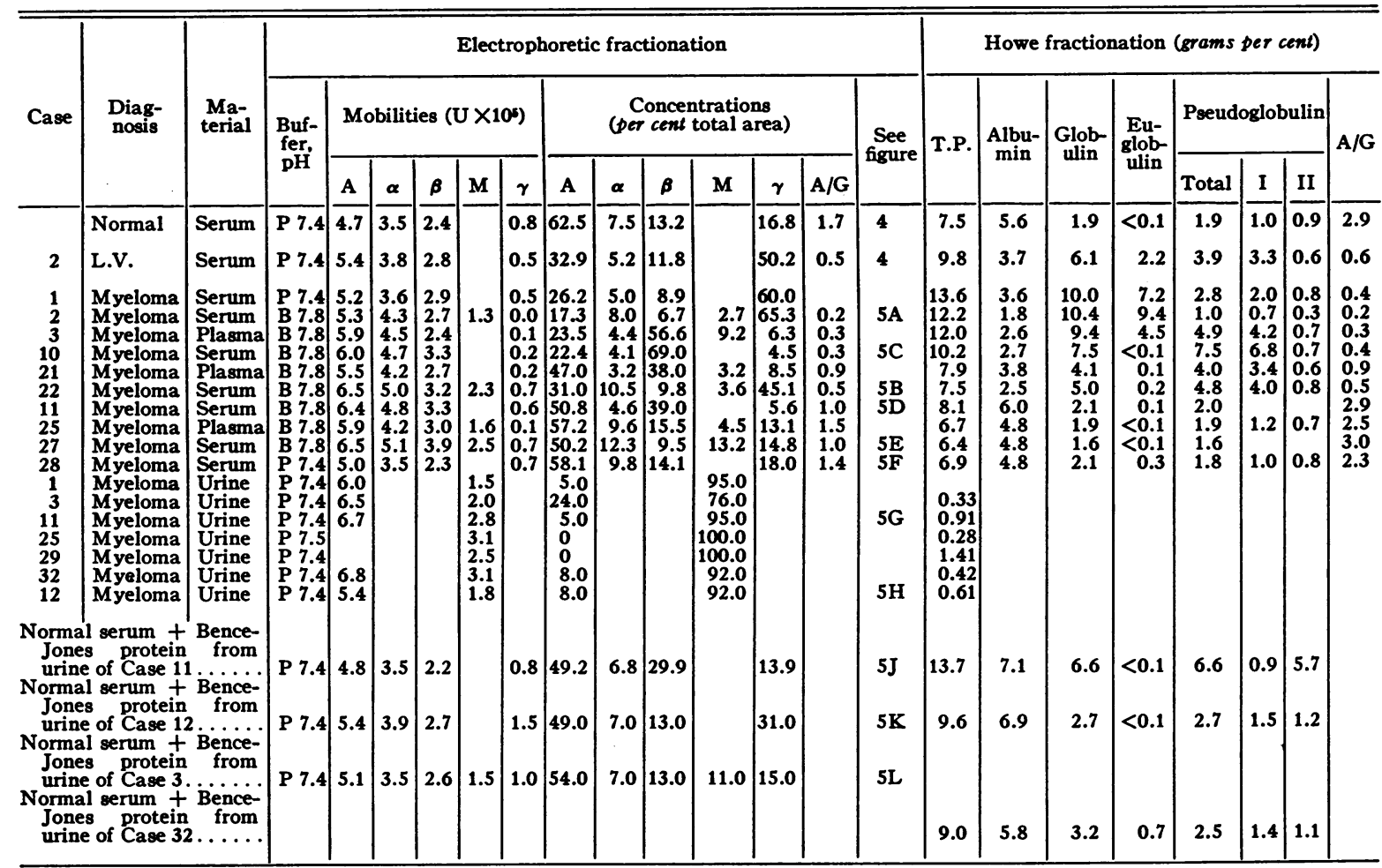

$\mathbf{P}=$ phosphate buffer, $\mathbf{B}=$ barbiturate buffer.

Figures for electrophoretic mobilities and concentrations in plasma of myeloma Cases 3, 21, 25 from Longsworth, Shedlovsky and MacInnes (4). The concentration of $M$ in these runs with plasma includes fibrinogen. All our concentrations are stated as per cent total refractive increment rather than in terms of albumin concentration because of the marked differences in albumin concentration in different cases of myeloma.

but, as no satisfactory method for quantitation of Bence-Jones proteins in serum is available, it is not known whether concentrations sufficient to cause hyperproteinemia develop and, if so, how frequently. Some of the older data indicating large accumulations in the blood are subject to the criticism $(5,6)$ that the methods employed do not discriminate adequately between Bence-Jones proteins and euglobulins. These criticisms appear not to apply to more recent estimations based on extraction (46, and others), protein solubility curves (52) and ultracentrifugation (53).

We have already described anomalous serum protein patterns encountered (in our experience) only in multiple myeloma. When the Howe method is used, these include occasional falsely high albumin values due to an abnormal protein in the 21.5 per cent sodium sulfate filtrate; hyperglobulinemia due wholly to an increase in the fraction precipitable in $\mathbf{1 7 . 4}$ per cent sodium sulfate, or partly to an increase in the fraction precipitable in 21.5 per cent sodium sulfate. Electrophoretically, abnormal components have been described with mobilities between or overlapping the mobilities of the $\beta$ and $\gamma$ globulins. These peculiarities become significant when considered in connection with the salting-out and electrophoretic behavior of Bence-Jones protein in urine. They can be reproduced, in part, by adding Bence-Jones protein from urine to normal serum.

The precipitation limits of Bence-Jones proteins in urine vary widely in different cases of multiple myeloma. If ammonium sulfate is used, precipitation may begin anywhere between the concentration employed to throw down the more soluble euglobulins to that required to salt out albumins (54). However, in most cases precipitation begins at $\mathbf{4 0} \pm 2$ per cent saturation 
(the concentration used to salt out "pseudoglobulin I" from serum (55)) and ends at $50 \pm 5$ per cent saturation ((54); personal observations). If sodium sulfate is used in urine not made strongly acid, the bulk of the Bence-Jones proteins usually remains in solution in $1.5 \mathrm{M}$ filtrates; if such Bence-Jones proteins were present in serum and there showed the same solubility relations, they would appear largely in the albumin filtrates and give falsely high albumin values. In some urine samples (Cases $1,3,11,32,33$, for example), partial precipitation of Bence-Jones proteins occurs in 21.5 per cent sodium sulfate, and in the urine of Cases 1, 3, 11 and 33, slight precipitation was observed also in $\mathbf{1 7 . 4}$ per cent but not in $\mathbf{1 3 . 5}$ per cent sodium sulfate solution; such proteins, if present in serum, presumably would appear in the "pseudoglobulin II" fraction or in both the "pseudoglobulin II" and "pseudoglobulin I" fractions. Correlations between the findings in serum and urine must necessarily be imperfect, however, if the concentrations in serum are sufficiently reduced by leakage through the kidneys.

Table IV gives the results of experiments in which urinary Bence-Jones proteins were added to normal serum of the composition indicated in that table. Of the Bence-Jones protein from the urine of Case 11 added to normal serum in an amount equivalent to 6.2 grams per cent, onefourth appeared in the Howe albumin fraction, three-fourths precipitated out with the globulins; the latter coming down entirely in the "pseudoglobulin II" fraction. Of the Bence-Jones protein from the urine of Case 12 added to normal serum in an amount equivalent to 2.1 grams per cent, about three-fifths remained in the Howe albumin fraction, two-fifths precipitated out with the globulins; the latter being divided between the "pseudoglobulin I" and "II" fractions in the proportions $3: 2$. Of the Bence-Jones protein from the urine of Case 32 added to normal serum in an amount equivalent to 1.5 grams per cent, about 90 per cent was precipitated out with the globulins; about one-half of the latter appearing in the "euglobulin" fraction, onefourth in the "pseudoglobulin I" fraction and one-sixth in the "pseudoglobulin II" fraction. We have not been able as yet to reproduce in this way large increases solely in the "pseudoglobulin
I" fraction. Nor have we been able to duplicate by such means large increases wholly or very largely in the "euglobulin" fraction, as anticipated from the studies of Magnus-Levy $(6,45)$ who showed that the "euglobulin" fraction in multiple myeloma usually contains little or no Bence-Jones protein.

The electrophoretic data on Bence-Jones proteins available to us included published values for three preparations (56) and unpublished values obtained (by E. A. K. while at Cornell Medical College) in a sample kindly furnished by Dr. V. DuVigneaud. Table IV includes additional data in 7 cases of multiple myeloma. Figure 5 shows the patterns obtained in Cases $11(\mathrm{G})$ and $12(\mathrm{H})$, the latter pattern indicating inhomogeneity.

It was found that, even under the uniform conditions of these determinations, the mobilities of the urinary Bence-Jones proteins of different patients differed widely-variations not wholly ascribable to differences in concentration, as indicated by dilution experiments. Using sodium phosphate buffer, $\mathrm{pH} \mathrm{7.4, \mu}=0.1$, the mobilities varied from 3.1 in Case 32 to 1.8 in Case 12 (Table IV).

Upon the addition of urine containing BenceJones protein to normal serum, the patterns obtained showed larger peaks at mobilities corresponding with the mobilities of the Bence-Jones proteins in the original urine samples. For example, addition of urine from Case 11 (containing Bence-Jones protein with mobility 2.8 ) resulted in an increase in the $\beta$ component of normal serum (Figure $5 \mathrm{~J}$ ), also a corresponding further increase in the $\beta$ component when the urine was added to a sample of the patient's serum. Addition of urine from Case 12 (containing BenceJones protein with mobility 1.8 ) resulted in an increase in the $\gamma$ peak of normal serum (Figure 5K). Addition of urine from Case 3 (containing Bence-Jones protein with an intermediate mobility of 2.0) resulted in the appearance of an intermediate $M$ peak in normal serum (Figure 5L). The $\gamma$ and $M$ peaks in Figure 5L are not completely separated because of the small difference in mobilities.

It was thus possible, by adding urinary BenceJones proteins to normal serum, and superimposing peaks due to Bence-Jones proteins upon 
normal serum patterns, to reproduce in all essentials the several electrophoretic patterns encountered in the sera of our cases of multiple myeloma (cf. Figures 5D and J; A and K; E and L). The results further suggest that the apparent discrepancies between the results of Howe and electrophoretic analyses in some myelomatous sera are ascribable, in large part, to the presence of Bence-Jones proteins in those sera.

\section{SUMMARY}

Howe and electrophoretic analyses of the serum proteins were made in normal adults, in cases with hyperproteinemia due to various chronic infections or to cirrhosis, and in cases of multiple myeloma.

Results with the Howe method (carried out with minimal filtration error) are recorded in 36 normal subjects. The spread and the mean values, in grams per cent, were: For total proteins, 7.9 to 6.5 (7.2); for albumins, 5.7 to 4.7 (5.2); for total globulins, 2.5 to $1.3(2.0)$; for "euglobulin," 0.4 to $<0.1$ (0.2); for "pseudoglobulin I," 1.9 to 0.8 (1.3); for "pseudoglobulin II," 0.8 to $0.2(0.5)$. Electrophoretic patterns of normal human serum fractionally precipitated with sodium sulfate are presented.

Serum protein partitions by the Howe method are recorded in 10 cases of lymphogranuloma venereum, 10 cases of cirrhosis, 5 cases of sarcoid and 15 miscellaneous infections, all illustrating the distribution of Howe fractions in hyperglobulinemia. In these and in additional cases of similar etiology, hyperglobulinemia was found to be the result of a marked absolute and relative increase in the "euglobulin" fraction, associated with a less sustained absolute rise in "pseudoglobulin I"; the latter fraction showing a relative decrease in the higher globulin ranges. Marked hyperglobulinemia due solely to one or the other of these two fractions, or to "pseudoglobulin II," was not observed in this group. These relations, brought out particularly by graphic analysis, are compared with electrophoretic results in serum of high globulin content before and after fractional precipitation with sodium sulfate.

Serum protein studies by the Howe method in 38 cases of multiple myeloma are recorded. In some cases, hyperglobulinemia resulted from increase in both "euglobulin" and "pseudo- globulin I" fractions, as in other diseases, though often in atypical proportions. In other cases anomalous results were obtained: the increase involved only the "pseudoglobulin I" fraction without any accompanying rise in "euglobulin," or the "pseudoglobulin II" or albumin fractions appeared to exceed maximal normal limits. Electrophoretic analyses in 10 cases gave similarly varied results: an increase in components moving with the mobility of $\gamma$ globulins, of $\beta$ globulins, or of globulins with intermediate mobilities forming a distinct $M$ boundary. These anomalous Howe and electrophoretic patterns were found to be of value in diagnosis.

The significance of these peculiarities is considered in relation to the analogous salting-out and electrophoretic properties of urinary BenceJones proteins. It is shown that the broad zones of precipitation and the different mobilities of Bence-Jones proteins obtained from the urine of different cases of multiple myeloma correspond with the several anomalies observed in the Howe and electrophoretic fractionation of myelomatous sera. By adding urinary BenceJones proteins from different patients to normal serum, the essential characteristics of some anomalous Howe patterns and of all electrophoretic patterns observed in myelomatous sera could be reproduced.

Apparently, most myelomatous sera fall into one of three classifications: (1) Sera with hyperglobulinemia due to an increase chiefly in the Howe "euglobulin" fraction, partly in the "pseudoglobulin I" fraction; electrophoretically, to an increase in $\gamma$ components. The globulin increment in these cases usually includes little or no Bence-Jones protein but is comparable to that observed in chronic infections. (2) Sera with or without hyperglobulinemia giving a variety of anomalous patterns by the Howe or electrophoretic methods, for the most part due to significant Bence-Jones proteinemia. It is not known whether in some such sera Bence-Jones proteins may occur in combination with other serum proteins. (3) Sera of apparently normal composition with respect to serum proteins.

We are indebted to the many physicians who permitted study of their cases of multiple myeloma; further to Dr. F. E. Kendall, Dr. L. G. Longsworth, Dr. T. Shedlovsky 
and Dr. D. A. MacInnes for suggestions; and to Miss Sheila Goldsmith for technical assistance in the electrophoretic analyses.

\section{BIBLIOGRAPHY}

1. Cohn, E. J., The properties and functions of the plasma proteins, with a consideration of the methods for their separation and purification. Chem. Rev., $1941,28,395$.

2. Howe, P. E., The determination of proteins in blooda micro method. J. Biol. Chem., 1921, 49, 109.

3. Tiselius, A., A new apparatus for electrophoretic analysis of colloidal mixtures. Trans. Faraday Soc., 1937, 33, 524.

4. Longsworth, L. G., Shedlovsky, T., and MacInnes, D. A., Electrophoretic patterns of normal and pathological human blood serum and plasma. J. Exper. Med., 1939, 70, 399.

5. Perlzweig, W. A., Delrue, G., and Geschickter, C., Hyperproteinemia associated with multiple myelomas. J. A. M. A., 1928, 90, 755.

6. Magnus-Levy, A., Multiple Myelome. VII. Euglobulinämie. Zur Klinik und Pathologie. Amyloidosis. Ztschr. f. klin. Med., 1933, 126, 62.

7. Feller, A. E., and Fowler, W. M., Hyperproteinemia in multiple myeloma. J. Lab. and Clin. Med., 1938, 23, 369.

8. Bing, J., Further investigations on hyperglobulinemia. I. Occurrence and degree of hyperglobulinemia in the various diseases. The ratio between hyperglobulinemia, hyperproteinemia and hypoalbuminemia. The formol-gel reaction. Acta med. Scandinav., 1940, 103, 547.

9. Jeghers, H., and Selesnick, S., Hyperproteinemia: Its significance. Internat. Clin., September, 1937, 47, 248.

10. Gros, W., Zur Frage gesetzmässiger Veränderungen des Bluteiweissbildes beim multiplen Myelom. Deutsches Arch. f. klin. Med., 1935, 177, 461.

11. Gutman, A. B., and Wise, C. R., Positive formol-gel reaction associated with hyperglobulinemia in lymphogranuloma inguinale, multiple myeloma and hepatic cirrhosis. Proc. Soc. Exper. Biol. and Med., 1936, 35, 124.

12. Snapper, I., Maladies Osseuses. Masson, Paris, 1938, p. 141.

13. Kekwick, R. A., The serum proteins in multiple myelomatosis. Biochem. J., 1940, 34, 1248.

14. Stover, N. M., and Sandin, R. B., Use of boric acid in micro-Kjeldahl determination of nitrogen. Industrial and Eng. Chem., Analytical Ed., 1931, 3, 240.

15. Robinson, H. W., Price, J. W., and Hogden, C. G., The estimation of albumin and globulin in blood serum. I. A study of the errors involved in the filtration procedure. J. Biol. Chem., 1937, 120, 481.

16. Svensson, H., Direkte photographische Aufnahme von Elektrophorese-Diagrammen. Kolloid Ztschr., 1939, 87, 181.
17. Longsworth, L. G., A modification of the Schlieren method for use in electrophoretic analysis. J. Am. Chem. Soc., 1939, 61, 529.

18. Harris, R. C., The adsorption of protein by filter paper in the estimation of albumin in blood serum. J. Biol. Chem., 1939, 127, 751.

19. Kendall, F. E., The use of immunochemical methods for the identification and determination of human serum proteins. Cold Spring Harbor Symposia on Quantitative Biol., 1938, 6, 376.

20. Howe, P. E., The use of sodium sulfate as the globulin precipitant in the determination of proteins in the blood. J. Biol. Chem., 1921, 49, 93.

21. Butler, A. M., Blatt, H., and Southgate, H., The solubility of the plasma proteins. II. Dependence on $\mathrm{pH}$, temperature, and lipid content in concentrated solutions of potassium phosphate and application to their separate precipitation. J. Biol. Chem., 1935, 109, 755.

22. Williams, R. D., and Gutman, A. B., Hyperproteinemia with reversal of the albumin : globulin ratio in lymphogranuloma inguinale. Proc. Soc. Exper. Biol. and Med., 1936, 34, 91.

23. Gutman, A. B., Systemic manifestations of lymphogranuloma venereum. N. Y. State J. Med., 1939, 39, 1420.

24. Jones, C. A., and Rome, H. P., Serum proteins, Takata-Ara reaction, and liver function tests in lymphogranuloma venereum. Am. J. Clin. Path., 1939, 9, 421.

25. Kampmeier, R. H., Smith, D. W., and Larsen, R. M., Blood studies in lymphogranuloma venereum; with special reference to serum proteins. Am. J. M. Sc., 1939, 198, 516.

26. Schamberg, I. L., The course of the plasma protein changes in early lymphopathia venereum under treatment with sulfanilamide. Am. J. M. Sc., 1941, 201, 67.

27. Peters, J. P., and Eisenman, A. J., The serum proteins in diseases not primarily affecting the cardiovascular system or kidneys. Am. J. M. Sc., 1933, 186, 808.

28. Ling, S. M., Distribution of protein fractions in the serum of kala-azar patients. Proc. Soc. Exper. Biol. and Med., 1930, 27, 247.

29. D'Antona, L., and Pellegrini, M., Sul meccanismo intimo e sul significato della reazione di TakataAra-Jezler. Diagn. e tecnica d. labor., 1934, 5, 372.

30. Gutman, A. B., and others, Acid-base equivalence of the blood in diseases associated with hyperglobulinemia; with special reference to lymphogranuloma inguinale and multiple myeloma. J. Clin. Invest., 1936, 15, 475.

31. Gros, W., Das Bluteiweissbild und seine Bedeutung für den Mechanismus der Takata-Reaktion. Ztschr. f. d. ges. exp. Med., 1937, 101, 519.

32. DeVries, A., Over de reactie van Takata-Jezler en haar variant, de reactie van Mancke-Sommer, over de formolgelreactie, en over het verband dezer reacties 
met de globulinefracties van het bloed. Thesis, University of Amsterdam, 1938.

33. Gutman, A. B., and Gutman, E. B., Relation of serum calcium to serum albumin and globulins. J. Clin. Invest., 1937, 16, 903.

34. Wise, C. R., and Gutman, A. B., The formol-gel reaction. A convenient preliminary test for hyperglobulinemia. Am. J. M. Sc., 1937, 194, 263.

35. Cohn, E. J., and others, Preparation and properties of serum and plasma proteins. I. Size and charge of proteins separating upon equilibration across membranes with ammonium sulfate solutions of controlled $\mathrm{pH}$, ionic strength and temperature. J. Am. Chem. Soc., 1940, 62, 3386.

36. Luetscher, Jr., J. A., Electrophoretic analysis of plasma and urinary proteins. J. Clin. Invest., 1940, 19, 313.

37. Svensson, H., Fractionation of serum with ammonium sulfate and water dialysis, studied by electrophoresis. J. Biol. Chem., 1941, 139, 805.

38. Talbott, J. H., and others, Dermatomyositis with scleroderma, calcinosis and renal endarteritis associated with focal cortical necrosis. Arch. Int. Med., 1939, 63, 476.

39. Drinker, N., Green, A. A., and Hastings, A. B., Equilibria between calcium and purified globulins. J. Biol. Chem., 1939, 131, 641.

40. Holman, R. L., Complete anuria due to blockage of renal tubules by protein casts in a case of multiple myeloma. Arch. Path., 1939, 27, 748.

41. Gutman, A. B., Tyson, T. L., and Gutman, E. B., Serum calcium, inorganic phosphorus and phosphatase activity in hyperparathyroidism, Paget's disease, multiple myeloma and neoplastic disease of the bones. Arch. Int. Med., 1936, 57, 379.

42. Fowler, E. P., Multiple myeloma involving the temporal bone. Laryngoscope, 1938, 48, 319.
43. Berglund, H., and Medes, G., The Kidney in Health and Disease. Lea and Febiger, Philadelphia, 1935, p. 534.

44. Albers, D., Multiple Myelome und Viscosität. Ztschr. f. klin. Med., 1937, 132, 807.

45. Magnus-Levy, A., Multiple Myelome (XII). Acta med. Scandinav., 1938, 95, 217.

46. Cantarow, A., Bence-Jones proteinemia in multiple myeloma. Am. J. M. Sc., 1935, 189, 425.

47. Wintrobe, M. M., and Buell, M. V., Hyperproteinemia associated with multiple myeloma. Bull. Johns Hopkins Hosp., 1933, 52, 156.

48. Von Bonsdorff, B., Groth, H., and Packalén, T., On the presence of a high-molecular crystallizable protein in blood serum in myeloma. Folia haemat., 1938, 59, 184.

49. Foord, A. G., and Randall, L., Hyperproteinemia, autohemagglutination and renal insufficiency in multiple myeloma. Am. J. Clin. Path., 1935, 5, 532.

50. Sweigert, C. F., Multiple myeloma with hyperproteinemia: Case report. Am. J. M. Sc., 1935, $190,245$.

51. Chester, W., Multiples Myelom und Hypoproteinämie. Ztschr. f. klin. Med., 1933, 124, 466.

52. Kydd, D. M., Bence-Jones protein in serum. J. Biol. Chem., 1934, 107, 747.

53. Packalén, T., A case of myeloma with spontaneously crystallizing protein in blood serum and urine. Acta med. Scandinav., 1939, 100, 1.

54. Magnus-Levy, A., Über krystallisiertes und amorphes Bence-Jones Eiweiss. Multiple Myelome IX. Ztschr. f. physiol. Chem., 1936, 243, 173.

55. Howe, P. E., The relative precipitating capacity of certain salts when applied to blood serum or plasma and the influence of the cation in the precipitation of proteins. J. Biol. Chem., 1923, 57, 241.

56. Svedberg, T., and Pedersen, K. O., The Ultracentrifuge. Clarendon Press, Oxford, 1940, p. 381. 